Review Article

\title{
Zingiber officinale (Ginger): A Future Outlook on Its Potential in Prevention and Treatment of Diabetes and Prediabetic States
}

\author{
Basil D. Roufogalis \\ Discipline of Pharmacology, School of Medical Sciences, Sydney Medical School, University of Sydney, Sydney, NSW 2006, Australia \\ Correspondence should be addressed to Basil D. Roufogalis; basil.roufogalis@sydney.edu.au
}

Received 3 March 2014; Revised 20 June 2014; Accepted 25 June 2014; Published 23 September 2014

Academic Editor: Eric Hajduch

Copyright (C) 2014 Basil D. Roufogalis. This is an open access article distributed under the Creative Commons Attribution License, which permits unrestricted use, distribution, and reproduction in any medium, provided the original work is properly cited.

Diabetes is reaching pandemic levels in both developing and developed countries and requires safe, affordable, and effective therapies. This report summarises work in our laboratory on the effects of Zingiber officinale (ginger) and its components in diabetes models and provides a future outlook on the potential for their use in type 2 diabetes. A high fat diet rat model showed modulation of body weight gain and normalisation of glucose and lipid metabolic disturbances, with reduction of insulin resistance in a high fat-high carbohydrate diet model. Ginger extract inhibits enhanced NF- $\kappa$ B in liver of high fat-fed rats through inhibition of the $\mathrm{IKK} / \mathrm{I} \kappa \mathrm{B} \alpha / \mathrm{NF}-\kappa \mathrm{B}$ classical pathway. The major active component (S)-[6]-gingerol inhibited elevated cytokines in inflamed HuH7 cells through suppression of COX2 expression and protection against the ROS pathway. Ginger extract and gingerols enhanced glucose uptake in L6 myotubes, by enhancing translocation of GLUT4 to the surface membrane and activation of AMPK $\alpha 1$ through $\mathrm{a} \mathrm{Ca}^{2+} /$ calmodulin-dependent protein kinase kinase pathway. (S)-[6]-Gingerol also enhanced energy metabolism through marked increment of peroxisome proliferator-activated receptor- $\gamma$ coactivator- $1 \alpha$ (PGC-1 $\alpha$ ) gene expression and mitochondrial content in L6 skeletal muscle cells. Future studies will require well designed clinical trials on ginger preparations of defined chemical composition.

\section{Introduction}

1.1. Diabetes and Prediabetic States: The Scope of the Problem. According to recent estimates the prevalence of diabetes has reached pandemic proportions, with 382 million people worldwide living with this condition. A further 316 million (6.9\%) adults worldwide with impaired glucose tolerance are at high risk of developing diabetes [1]. By the end of 2013 it was estimated that there would be 5.1 million deaths and a cost of USD 548 million in health care spending. Estimates indicate that there will be 592 million people living with the disease within 25 years without positive action, yet it is considered that most of these cases are preventable [1]. Contrary to expectations, $80 \%$ of people with diabetes live in low- and middle-income countries [1]. There is also a growing trend for younger people to develop diabetes, leading to an increasing incidence of premature deaths [2].

Diabetes mellitus is characterised by chronic hyperglycemia resulting from impaired insulin action/secretion [3]. Type 2 diabetes, accounting for $>90 \%$ of diabetes [3], is associated with metabolic disorders of both lipid and carbohydrate [4]. Effective control of hyperglycemia in diabetic patients is critical for reducing the risk of micro- and macrovascular disease [5-7]. The recent growth in obesity is associated with lifestyle changes, especially increased caloric intake and decreased physical activity. Obesity is associated with an increased prevalence of chronic diseases, including type 2 diabetes mellitus with insulin resistance, atherosclerosis, and nonalcoholic fatty liver disease (NAFLD) [8-10]. Although lifestyle changes including exercise and better nutrition have been found effective in reducing the debilitating effects of diabetes, these changes have been difficult to implement and the battle is being lost [11]. Therapy therefore continues to rely heavily on pharmacological agents, but side effects of varying severity of the presently available hyperglycemic agents, especially in the elderly, have limited their usefulness as antidiabetic agents. This has led to continued efforts to explore the effectiveness and potential of agents from natural sources for the control of diabetes mellitus. A vast array of plant and related products with antidiabetic effects were 
<smiles>CCCCCCCCCCCCCCCC(=O)CCc1ccc(O)c(OC)c1</smiles>

Gingerols

[6]-S-Gingerol $(n=4)$

[8]-S-Gingerol $(n=6)$

[10]-S-Gingerol $(n=8)$

Sesquiterpenes

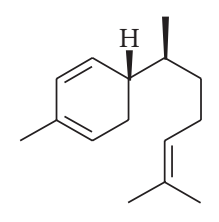

(-)-Zingiberene

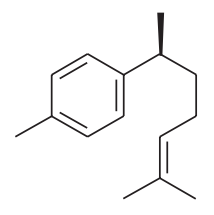

ar-Curcumene<smiles>CCCCCCCCCCC(=O)CCc1ccc(O)c(OC)c1</smiles>

Shogaols

[6]-Shogaol $(n=4)$

[8]-Shogaol $(n=6)$

[10]-Shogaol $(n=8)$

FIGURE 1: Chemical structures of components of Zingiber officinale.

identified in reviews of the literature on natural products $[12,13]$. Metformin, currently the drug of choice in the management of hyperglycemia, in fact has its origins in a natural product [14]. The combination of hyperglycemic and hyperlipidemic disturbances and their interdependence presents major risk factors for the development of diabetes and its life threatening cardiovascular complications [15]. Thus the control of both these underlying disturbances is considered optimal for the management of diabetes and its complications.

1.2. Ginger. Ginger (Zingiber officinale, Roscoe Zingiberaceae) is one of the most widely consumed spices worldwide. From its origin in Southeast Asia and its spread to Europe, it has a long history of use as herbal medicine to treat a variety of ailments, including vomiting, pain, indigestion, and cold-induced syndromes [16, 17]. Although ginger is not widely known for its effectiveness in diabetes prevention and/or treatment, modern pharmacological studies support its potential for treating both the hyperlipidemic and hyperglycemic aspects of diabetes. However there is much less information on the mechanism of action of ginger underlying its effects in diabetes. Whilst the chemical composition of Zingiber officinale is well investigated, it is much less clear which of the many components in ginger are responsible for its effects in diabetes.

1.3. The Importance of Chemical Composition of Ginger and Other Herbal Products. It is expected that the multiple components in ginger may lead to multiple effects on metabolic pathways and to involve multiple mechanisms affecting various aspects of chronic metabolic disorders such as diabetes [18]. Some of the main chemical components of ginger are shown in Figure 1. Crude ginger contains up to 9\% lipids or glycolipids and about $5-8 \%$ oleoresin. The pungent principles, accounting for $25 \%$ of the oleoresins, consist mainly of gingerols. [6]-Gingerol is the major gingerol, and other gingerols include [8]-gingerol or [10]-gingerol, as well as methylgingerol and gingerdiol, dehydrogingerdione, [10]dehydrogingerdione, diarylheptanoids, diterpene lactones, and galanolactone (in some species). Ginger contains up to $3 \%$ essential oil, accounting for $20-25 \%$ of the oleoresins. Gas chromatography/mass spectrometry identified other numerous compounds in the essential oil of ginger, of which major compounds are camphene, b-phellandrene, and 1,8-cineol [19]. The oil also contains sesquiterpenes and sesquiterpene alcohols impacting the smell of ginger, whilst the taste of ginger is mainly affected by various monoterpenes. Shogaols, contained in semidried ginger, are more pungent than gingerols [20], are a major degradation product of the thermally labile gingerols, and are rarely found in fresh ginger [21]. Another minor component, zingerone, is a degradation product which indicates low quality plant material. A number of other coactive constituents could also contribute to the treatment of various diseases.

1.4. Evidence for Efficacy from Clinical and Pharmacological Studies on Ginger. Sigrun Chrubasic, in collaboration with our laboratory, undertook a comprehensive review of animal and clinical studies on Zingiber officinale [18]. In nausea and vomiting it was concluded that clinical evidence beyond doubt is only available for pregnancy-related nausea and vomiting, whilst meta-analyses could not demonstrate effectiveness in postoperative nausea, motion sickness, or nausea/vomiting of other aetiology. It remains to be confirmed to what extent various proprietary ginger preparations are clinically useful to alleviate osteoarthritic or other pains and to influence platelet aggregation. Ginger exerts in vitro antioxidative, antitumorigenic, and immunomodulatory effects and is an effective antimicrobial and antiviral agent. Animal 
studies demonstrate effects on the gastrointestinal tract, the cardiovascular system, and experimental pain and fever and antioxidative, antilipidemic, and antitumor effects, as well as central and other effects. More recently Li et al. [26] from our group reviewed in vitro, in vivo, and clinical studies on the effectiveness of ginger in diabetes, diabetic complications, and associated lipid and other metabolic disorders, with particular emphasis on the mechanisms underlying the antihyperglycemic effects of ginger. Prominent mechanisms underlying these actions are found to be associated with insulin release and action and improved carbohydrate and lipid metabolism. Ginger has shown prominent protective effects on diabetic liver, kidney, eye, and neural system complications.

1.5. Aims and Objectives of This Report. Studies on Zingiber officinale in inflammatory conditions have been undertaken in this laboratory since 2001. Our objective has been to validate the traditional and modern literature on the effectiveness of ginger in chronic metabolic conditions and to provide new potential therapeutic modalities based on a thorough understanding of the underlying molecular mechanisms of action of Zingiber officinale and in particular its major active components. Given the still unmet needs of treatment of diabetes and its complications we have focused our efforts on the potential of ginger for the prevention and treatment of the underlying causes of diabetes and the prediabetic state. Natural products may provide safer and more accessible materials for the prevention of diabetes and its treatment in both the developed and developing world. This report reviews our studies and provides a perspective and future outlook for additional research and development needed to provide new therapies based on ginger as a natural product. The methods employed are found in detail in the original articles cited.

\section{Ginger in Animal Models of Diabetes and Prediabetes}

The concept of "reverse pharmacology" [27] often applies to research in herbal medicine, whereby a plant or other natural products with a history of safe and traditional use undergo scientific evaluation to validate that traditional use and to understand the likely major mechanisms of action. Animal studies are widely used, especially for the validation phase, as such models are of value to study both preventative aspects and management of the condition under investigation. Initially studies have been undertaken to investigate the effects of Zingiber officinale (ginger) in animals made hyperglycemic and hyperlipidemic by exposure to high fat diets, of the type often associated with some "cafeteria-style" foods consumed by humans. Although a number of animal model studies have been done, the results of our studies are summarized below. Related studies will be found in the original articles cited.

2.1. A High Fat Diet Model [28]. In the earliest model examined [28] we investigated the effect of an ethanolic extract of ginger (which contained not less than 10\% [6]-gingerol) on Wistar strain rats $(150-200 \mathrm{~g})$ fed with a high fat diet with moderate levels of carbohydrate. The high fat diet (HFD) contained $60 \%$ fat, $15 \%$ carbohydrate, $17.5 \%$ protein, $5 \%$ crude fibre, and $2 \%$ cholesterol. The HFD group was compared to a standard diet containing 5\% fat and 60\% carbohydrate. A 95\% ethanol extract of Zingiber officinale rhizome $(20: 1)$ prepared commercially was used in this study. The ethanol extract of Zingiber officinale was found by mass spectrometry to contain three major gingerol-related compounds, [6]-gingerol, [8]-gingerol, and [6]-shogaol (see Figure 1), at $1.56 \mathrm{mg} / \mathrm{g}$, $0.24 \mathrm{mg} / \mathrm{g}$, and $11.70 \mathrm{mg} / \mathrm{g}$, respectively.

Ethanolic ginger extract $(100-400 \mathrm{mg} / \mathrm{Kg})$ given by oral gavage for 6 weeks suppressed the body weight gain and lowered serum glucose and insulin induced by the high fat diet. It also dose-dependently increased insulin sensitivity, as determined by the Homeostatic Model Assessment of Insulin Resistance (HOMAR-IR) analysis. This effect was similar to that of the control rosiglitazone.

2.1.1. Effects of Ginger on Lipid Biochemical Markers [29]. Animal studies allow the testing of the effects of herbal extracts on lipid changes and key enzymes and gene and receptor expression in the chosen animal model. It is accepted that both hyperglycemia and dyslipidemia are important contributing factors to the development of atherosclerosis in type 2 diabetes [30] and hyperlipidemia represents a significant modifiable risk factor. In the HFD-treated rats [28] ginger extract effectively reduced the elevated levels of serum total cholesterol and LDL-cholesterol towards control levels, in addition to producing a marked reduction in elevated serum triglycerides, free fatty acids, and phospholipids. Similar results were found in another HFD study (60\% fat and 10.6\% carbohydrate), where Zingiber officinale extract $(400 \mathrm{mg} / \mathrm{kg}$ for 6 weeks) reduced the enhanced triglyceride levels and showed a small but not significant decrease in hepatic cholesterol level [29]. Rosiglitazone as a positive control had a similar effect. Zingiber officinale extract prevented the HFDinduced decrease in LDL receptor protein and increased HMG-CoA reductase protein in the liver of the HFD rats, both important mechanisms in the uptake and synthesis of cholesterol. By contrast, rosiglitazone $(3 \mathrm{mg} / \mathrm{kg}$ ) was without effect on these activities.

\subsection{Effects of Ginger on a High Fat, High Carbohydrate Ani-} mal Model with Insulin Resistance [31]. It is now widely recognized that a high calorie western food diet contributes greatly to the development of metabolic syndrome [32, 33]. Recent literature suggested that diets with high content of fat and simple carbohydrate, especially fructose, are strongly associated with insulin resistance [34-36]. We undertook a study of the effect of ginger extract on insulin resistance in rats fed with a high fat diet together with a high content of simple sugars (fructose and sucrose) [31].

The ginger extract in this study was a freeze-dried powder of ginger rhizome (Grade A, provided by Buderim Ginger Limited, Queensland, Australia) extracted with ethanol at low temperatures and reduced pressure, affording a total ginger extract containing 15.6\% (S)-[6]-gingerol. The HFHC diet (with simple sugars as the main carbohydrate source) 
contained $17.7 \%$ sucrose, $17.7 \%$ fructose, $19.4 \%$ protein, and $40 \%$ fat, with a digestible energy of $24.1 \mathrm{MJ} / \mathrm{kg}$; this contrasts with the standard chow with $59.4 \%$ total carbohydrate as cereal grain as the main carbohydrate source and $4.8 \%$ fat, containing digestible energy of $14.0 \mathrm{MJ} / \mathrm{kg}$. In contrast to our earlier study where rats were fed with a high fat $(60 \%)$ diet with moderate carbohydrate, the growth rate during the 10-week feeding of the HFHC group was not different from that of standard chow fed rats, possibly due to the lower amount of food consumption and similar digestive energy intake. An oral glucose tolerance test conducted over a period of 120 minutes at the end of week 10 resulted in a lower AUC of glucose in ginger extract $(200 \mathrm{mg} / \mathrm{kg})$ and metformin $(200 \mathrm{mg} / \mathrm{kg})$ treated rats compared to the HFHC control. In addition, higher serum insulin concentrations and a reduced HOMAR-IR in the HFHC diet, indicating development of insulin resistance, were markedly reversed by oral ginger extract $(200 \mathrm{mg} / \mathrm{kg})$ administration. Metformin also effectively ameliorated the HFHC diet-induced insulin resistance, as expected from clinical studies. It is of interest that in this study the ginger extract used was high in content of (S)-[6]-gingerol but not in shogaol.

Summary. We concluded from the high fat and high fat, high carbohydrate studies that the ethanolic extract of ginger showed remarkable protection from the diet-induced metabolic disturbances, especially insulin resistance, providing a rational basis for the potential medicinal value of the rhizome of Zingiber officinale and its traditional consumption for the prevention of glucose and lipid disorders.

2.3. Studies of Inflammatory Mechanisms in High Fat Diet Animal Models of Metabolic Syndrome and Prediabetes [23]. Another series of studies investigated the effect of ginger on inflammatory mediators in liver of high fat fed rats. The obesity explosion is associated with an increased prevalence of chronic diseases including type 2 diabetes mellitus [810] and a growing body of evidence supports the role of hepatic inflammation in the pathogenesis of these chronic diseases $[37,38]$. The anti-inflammatory properties of ginger have been known for centuries $[39,40]$ and a number of different laboratories showed that ginger extracts suppress inflammation through inhibition of the classical NF- $\kappa \mathrm{B}$ pathway in various cell types and tissues $[41,42]$. We therefore investigated the anti-inflammatory effect of ethanolic extract of Zingiber officinale on cytokine expression associated with hepatic NF- $\kappa$ B activity in the high fat diet (HFD) rat model.

Treatment with Zingiber officinale $(400 \mathrm{mg} / \mathrm{kg}$ ) was found to suppress the increased hepatic nuclear NF- $\kappa \mathrm{B}$ activation and the nuclear NF- $\kappa$ B levels in liver of the HFD-treated rats [23]. The ginger administration decreased hepatic expression of IL- 6 and TNF- $\alpha$, consistent with defence against inflammatory insult in the liver. We therefore concluded that Zingiber officinale ameliorates liver inflammation through suppression of the master inflammatory mediator NF- $\kappa \mathrm{B}$, decreasing the secretion of proinflammatory cytokines and chemokines which contribute to a feed-forward amplification of inflammatory signalling and progression of diabetes and metabolic syndrome [43]. These findings open the door to the potential development of ginger-based therapy for hepatic inflammation associated with the development of insulin resistance.

\section{Determining the Chemical Composition and the Major Active Components in Ginger}

Determining the mechanism of action of herbal medicines is a critical component of understanding the effects and mechanisms of action of natural products, assisting with validation and further understanding of the traditional knowledge and medicinal properties of natural products. Furthermore, establishing the mechanisms of action of major chemical components allows a deeper understanding of the overall biological and physiological effects observed. It also provides information of possible side effects and interactions with other drugs. Natural products typically have multiple effects, giving rise to multitarget action mechanisms from multiple pathways. As the pharmacological effects may be determined by the particular dose used, determining the potency of the various chemical components for various biological activities may predict the expected clinical effects of a herbal extract. We undertook fractionation of ginger to determine the most active components likely to be responsible for the observed antidiabetic activities, using glucose uptake in cultured L6 myotubes as the biological assay. The fractionation and activities of the resulting ginger extract fractions are illustrated in Figure 2. Fractionation of this extract using a hexane and ethyl acetate mixture gave fractions ranging from most nonpolar to moderately polar. Fraction F7 had the greatest glucose uptake activity and from ${ }^{1} \mathrm{H}-\mathrm{NMR}$ analysis was shown to be concentrated in (S)-[6]-gingerol (around 43.4\%). Other fractions contained smaller amounts of gingerols, as well as flavonoids, triterpenoids, fatty acids, and lipids, by NMR analyses. The effects of purified gingerols were subsequently determined in anti-inflammatory and myotube glucose uptake assays.

\section{Mechanism of Action of Ginger from In Vitro Studies}

\subsection{In Vitro Studies on the Inflammatory \\ Response in Hepatocytes}

4.1.1. Effects of Zingiber officinale on Inflammatory Markers. To further understand the mechanism of anti-inflammatory action of Zingiber officinale we undertook a series of studies to examine the effect of ginger extract in hepatocytes in vitro [23].

Cultured human hepatocyte (HuH-7) cells transfected with a NF- $\kappa$ B-luciferase reporter vector were incubated with Zingiber officinale $(100 \mu \mathrm{g} / \mathrm{mL})$ prior to exposure to interleukin- $1 \beta$ (IL- $1 \beta, 8 \mathrm{ng} / \mathrm{mL}$ for $3 \mathrm{~h}$ ) to induce an inflammatory phenotype. We showed first that increased NF- $\kappa \mathrm{B}$ activity induced by IL-1 $\beta$ exposure was markedly reduced by $16-36 \mathrm{~h}$ preincubation with Zingiber officinale. It was then shown that ginger extract treatment dose-dependently 

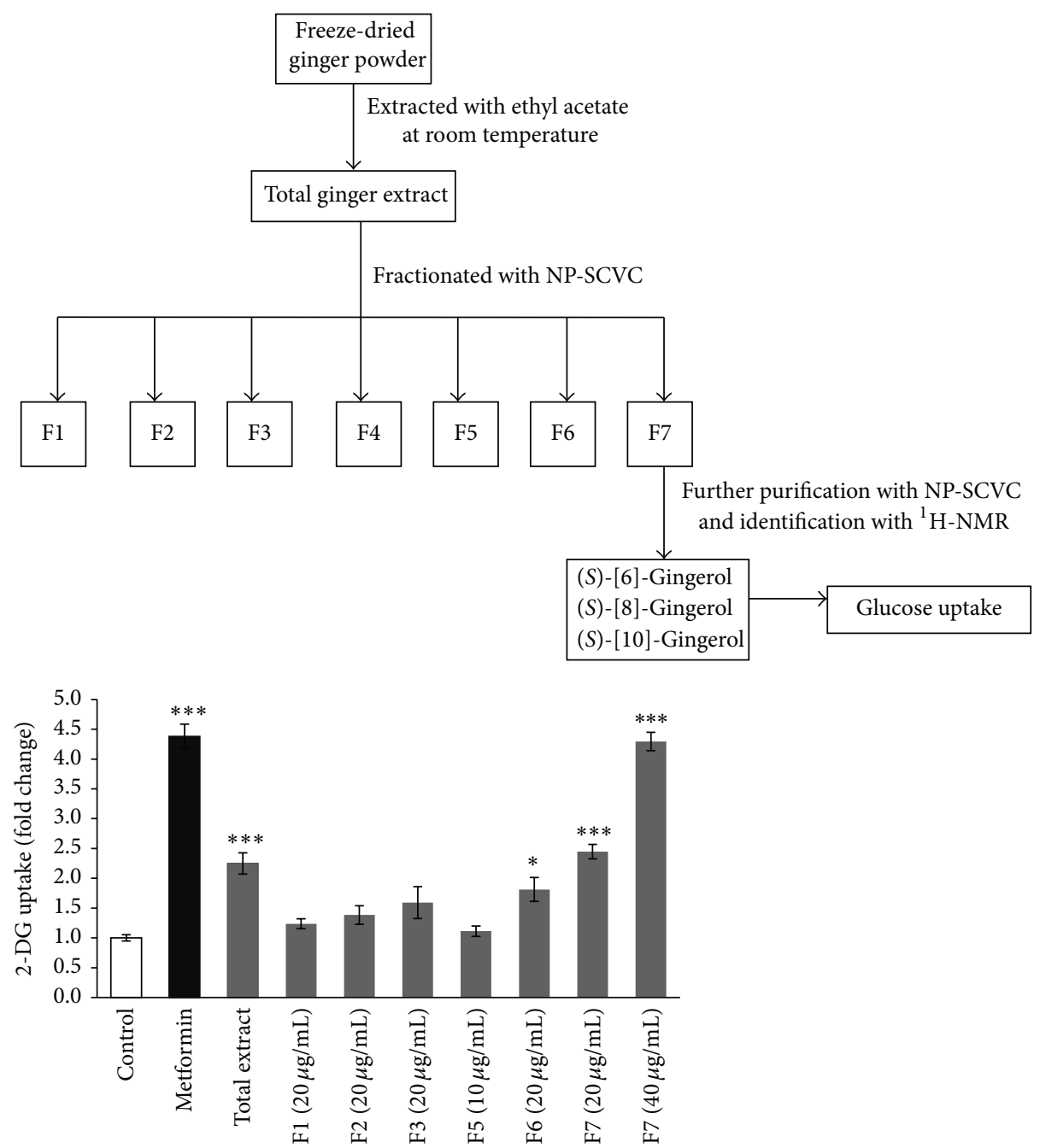

FIGURE 2: Fractionation of ginger and analysis and activity of chemical composition of major active fractions [22]. Freeze-dried ginger was extracted with ethyl acetate to give the total ginger extract containing 15\% (S)-[6]-gingerol, 1.7\% (S)-[8]-gingerol, 2.7\% (S)-[10]-gingerol, and $0.6 \%$ [6]-shogaol. Fractions were separated by short-column vacuum chromatography (NP-SCVC) into seven fractions from nonpolar to moderate polarity. The bar graph shows the 2-deoxyglucose uptake activities of the ginger extract, metformin, and fractions tested at the maximum noncytotoxic doses. ${ }^{1} \mathrm{H}-\mathrm{NMR}$ analysis showed that gingerols were the major constituents in F7. HPLC analysis of active fraction F7 indicated 43.4\% (S)-[6]-gingerol, 2.9\% (S)-[8]-gingerol, 1.5\% (S)-[10]-gingerol, and 0.07\% [6]-shogaol. The effect on glucose uptake was evaluated using radioactive labelled $2-\left[1,2-{ }^{3} \mathrm{H}\right]$-deoxy-D-glucose in L6 myotubes $[22-24]$. ${ }^{*} P<0.05$, ${ }^{* * *} P<0.001$.

decreased NF- $\kappa$ B-target inflammatory gene expression of IL6, IL-8, and serum amyloid A1 (SAA1). The decrease in SAA1 was of particular interest, since its secretion by hepatocytes is dramatically upregulated during an inflammatory response [44] and, given its central role in insulin resistance, may be a key pathway for the preventive effects of Zingiber officinale.

Under basal conditions nuclear factor-kappa B (NF$\kappa \mathrm{B})$ is present in the cytoplasm of hepatocytes in a latent form, bound to the NF- $\kappa$ B inhibitory protein, inhibitor kappa $\mathrm{B}(\mathrm{I} \kappa \mathrm{B} \alpha)$. Upon exposure to proinflammatory stimuli, the I $\kappa \mathrm{B}$ kinase (IKK) complex is activated and catalyses the phosphorylation of $\mathrm{I} \kappa \mathrm{B} \alpha$. Phosphorylated $\mathrm{I} \kappa \mathrm{B} \alpha$ is then targeted for degradation by the $26 \mathrm{~S}$ proteasome complex, thereby liberating NF- $\kappa \mathrm{B}$ to migrate to the cell nucleus and direct transcription of target genes [45]. We showed that the decrease in NF- $\kappa \mathrm{B}$ activity by ginger extract was associated with a large reduction of activated $\mathrm{I} \kappa \mathrm{B} \alpha$ kinase (IKK) activity relative to the vehicle control, whilst the degradation of the $\mathrm{NF}-\kappa \mathrm{B}$ inhibitory protein, $\mathrm{I} \kappa \mathrm{B} \alpha$, was considerably decreased relative to vehicle control in the IL- $1 \beta$-activated $\mathrm{HuH}-7$ cells. At these concentrations Zingiber officinale had little or no effect on cell viability. A schematic of the effects of ginger and its components on NF- $\kappa$ B pathways is shown in Figure 3.

4.1.2. Studies on Inflammatory Pathways with (S)-[6]-Gingerol [46]. To investigate the chemical component that may be responsible for the anti-inflammatory activities we investigated the effects of the major component (S)-[6]-gingerol on inflammatory pathways in hepatocytes. Our studies and other studies in the literature have shown that ginger extracts 


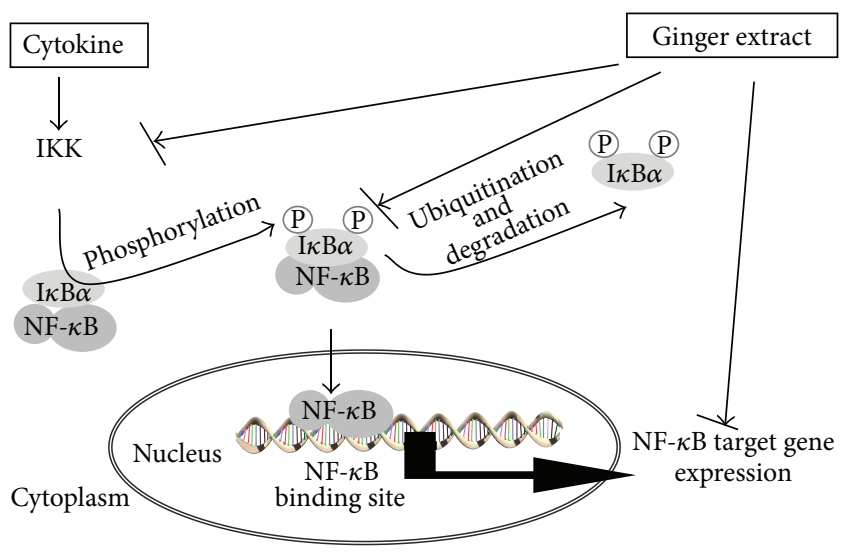

FIGURE 3: Influence of ethanolic ginger extract on the NF- $\kappa \mathrm{B}$ inflammatory pathway in liver. Ginger extract decreases NF- $\kappa$ Btarget inflammatory gene expression by suppression of NF- $\kappa \mathrm{B}$ activity, through stabilisation of inhibitory $\mathrm{I} \kappa \mathrm{B} \alpha$ and degradation of $\mathrm{I} \kappa \mathrm{B} \alpha$ kinase (IKK) activity (adapted from Li et al. [25]).

suppress inflammation through inhibition of the classical nuclear factor-kappa B (NF- $\kappa \mathrm{B})$ pathway in various cell types and tissues [42, 47]. Upon exposure to proinflammatory stimuli, activated NF- $\kappa \mathrm{B}$ directs transcription of target genes [45], including genes encoding cytokines, chemokines, and the enzyme cyclooxygenase 2 (COX2) [48]. Cyclooxygenase $(\mathrm{COX})$ is an important proinflammatory mediator and COX2 is responsible for persistent inflammation [49]. As (S)-[6]gingerol exhibits anti-inflammatory and antioxidant properties [50-52] we studied the mechanisms that underlie the anti-inflammatory effects of (S)-[6]-gingerol, isolated in our laboratory, in the IL1 $\beta$-treated HuH-7 hepatocyte cell model.

Pretreatment of $\mathrm{HuH}-7$ cells with (S)-[6]-gingerol for $6 \mathrm{~h}$ significantly inhibited IL1 $\beta$-induced NF- $\kappa$ B activity, suggesting that the protective effects of (S)-[6]-gingerol against IL1 $\beta$-induced inflammation are, at least in part, associated with inhibition of NF- $\kappa \mathrm{B}$ activation in $\mathrm{HuH}-7$ cells. Furthermore, (S)-[6]-gingerol attenuated IL1 $\beta$-induced inflammatory response, as evidenced by its decrease of mRNA levels of inflammatory interleukins IL-6 and IL-8 and serum amyloid A1 (SAA1). In keeping with this result, pretreatment with $50 \mu \mathrm{M}$ pyrrolidine dithiocarbamate (PDTC), a selective inhibitor of NF- $\kappa \mathrm{B}$, before exposure to IL- $1 \beta$ abrogated IL1 $\beta$ induced COX2, IL-6, IL-8, and serum amyloid A1 (SAA1) expression. (S)-[6]-Gingerol reduced IL1 $\beta$-induced COX2 upregulation, and as a control PDTC, the NF- $\kappa \mathrm{B}$ inhibitor also attenuated IL1 $\beta$-induced overexpression of COX2. It was also shown that the level of inhibition of the expression of IL6, IL-8, and SAA1 achieved by (S)-[6]-gingerol was similar to that mediated by the COX2 inhibitor NS-398, suggesting that the (S)-[6]-gingerol effect on these cytokines was mediated by COX2 inhibition. In earlier studies we had shown that gingerols inhibit COX2 directly [53]. Together, these data suggest that COX2 is most likely a central player in mediating the anti-inflammatory effects of (S)-[6]-gingerol.

4.1.3. Effects of (S)-[6]-Gingerol on ROS Pathways. In the next phase of this series of experiments we showed that
(S)-[6]-gingerol protects $\mathrm{HuH}-7$ cells against IL1 $\beta$-induced inflammatory response by suppression of reactive oxygen species (ROS) generation and increasing mRNA levels of antioxidant enzyme 24-dehydrocholesterol reductase (DHCR24). Decreasing oxidative stress underlies many antiinflammatory effects [54], and it is well recognized that inflammation is a manifestation of oxidative stress, which induces the pathways that generate the inflammatory factors, such as cytokines [55]. The effect of (S)-[6]-gingerol on IL1 $\beta$ induced oxidative stress was determined from its effects on intracellular superoxide and DHCR24 levels. Pretreatment of $\mathrm{HuH}-7$ cells with (S)-[6]-gingerol led to a decrease in superoxide generation induced by IL-1 $\beta$. The ability of $(S)$ [6]-gingerol to inhibit IL- $1 \beta$-induced NF- $\kappa \mathrm{B}$ activation and suppression of the expression of COX2 and IL-6, IL-8, and SAA1 paralleled the results we obtained when we treated the cells with the ROS scavenger, butylated hydroxytoluene (BHT). Together with the inhibitory effect on DHCR24 levels in $\mathrm{HuH}-7$ cell, the results indicate that $(S)$-[6]-gingerol exerts an antioxidative effect on IL- $1 \beta$-stimulated $\mathrm{HuH}-7$ cells and hence improvement in the cellular defence mechanisms. Given that antioxidant enzymes are able to block NF- $\kappa \mathrm{B}$ activation by various stimuli, our findings suggest that the anti-inflammatory effects of (S)-[6]-gingerol are mediated, at least in part, by suppressing oxidative stress.

4.2. Conclusions on Inflammation Studies. Our series of studies on the effects of Zingiber officinale and its major active component (S)-[6]-gingerol has shown that the natural product inhibits IL-6, IL-8, and SAA1 expression in cytokinestimulated HuH-7 cells, via suppression of COX2 expression through blockade of the NF- $\kappa \mathrm{B}$ signalling pathway. Hepatic inflammation can drive insulin resistance. (S)-[6]-Gingerol protects $\mathrm{HuH}-7$ cells against IL- $1 \beta$-induced inflammatory insults through inhibition of the ROS pathway. These results may open up novel treatment options whereby (S)-[6]gingerol could potentially protect against hepatic inflammation which underlies the pathogenesis of chronic diseases like insulin resistance and type 2 diabetes mellitus.

\subsection{Identifying the Gingerol Receptor and Calcium Signalling} Pathway in Hepatocytes [56]. Whilst much herbal medicines research has successfully determined signalling pathways at the enzyme and gene level, there is often a paucity of information on the receptor sites through which such effects are mediated. In our earlier studies we reported that [6]gingerol is an efficacious agonist of the capsaicin-sensitive transient receptor potential cation channel subfamily $\mathrm{V}$ member 1 (TRPV1) in neurons [57]. Gingerols possess the vanillyl moiety, which is considered important for activation of TRPV1 expressed in nociceptive sensory neurons [58]. Calcium signals in hepatocyte regulate glucose, fatty acid, amino acid, and xenobiotic metabolism [59, 60]. They mediate essential cellular functions, including cell movement, secretion, and gene expression, thereby controlling cell growth, proliferation, and cell death.

We therefore investigated if (S)-[6]-gingerol interacted with TRPV1 receptors in liver hepatocyte cells. We first 
<smiles>CCCCCCCCCC(=O)C(O)Cc1ccc(O)c(OC)c1</smiles>

(a)

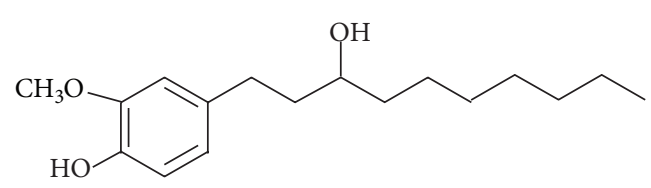

(b)

FIGURE 4: Structures of synthetic analogs of gingerol and shogaol. (a) 2-Hydroxy-1-(4-hydroxy-3-methoxyphenyl)dodecane-3-one (ZTX42). (b) [6]-Dihydroparadol (6-DHP).

determined if functional TRPV1 receptors were present in these cells. Exposure of HuH-7 cells to the TRPV1 channel agonist capsaicin $(10 \mu \mathrm{M})$ caused a significant increase in the mRNA levels of TRPV1. Application of $10 \mu \mathrm{M}$ capsaicin to cultured HuH-7 cells loaded with Fluo-4 probe also increased intracellular $\mathrm{Ca}^{2+}$ levels, an effect inhibited by the selective capsaicin inhibitor capsazepine. These data thus indicated that HuH-7 cells express the TRPV1 calcium channel. We found that (S)-[6]-gingerol dose-dependently induced a transient rise in $\mathrm{Ca}^{2+}$ in $\mathrm{HuH}-7$ cells, with the effect being abolished by preincubation with EGTA, an external $\mathrm{Ca}^{2+}$ chelator, and inhibited by the TRPV1 channel antagonist capsazepine. The rapid (S)-[6]-gingerol-induced NF- $\kappa$ B activation was found to be dependent on the calcium gradient and TRPV1 activation. A functional correlate of the $\mathrm{Ca}^{2+}$ dependence was also examined by investigating the effect of (S)-[6]-gingerol on the known antiapoptotic action of NF- $\kappa \mathrm{B}$ activation $[61,62]$. The rapid NF- $\kappa \mathrm{B}$ activation by (S)-[6]-gingerol increased mRNA levels of NF- $\kappa$ B-target genes cIAP-2, XIAP, and Bcl-2, which encode antiapoptotic proteins. Their expression was blocked by the TRPV1 antagonist capsazepine. The relationship between TRPV1 activation and the anti-inflammatory effects of (S)-[6]-gingerol remains to be clarified.

4.4. Effect of Gingerols on Nitric Oxide Pathways [63]. Inducible nitric oxide is an important proinflammatory mediator. Overproduction of NO or cytotoxic NO metabolites contribute to numerous pathological processes, including inflammation. We investigated the role of the nitric oxide pathway in the inhibitory effects of ginger in inflammation using stable metabolites and analogues of gingerols and shogaols in a macrophage system. The compounds, synthesised in our laboratory by Dr. Tran and A/Professor Duke, were analogues in which the $\alpha$-hydroxy ketone groups, were changed to more stable $\beta$-hydroxyketone (rac-2-hydroxy1-(4-hydroxy-3-methoxyphenyl)dodecan-3-one) or a single hydroxyl side chain-containing analog (rac-(6)-dihydroparadol) (Figure 4) [63]. Both compounds dose-dependently inhibited lipopolysaccharide- (LPS-) induced nitric oxide production. The inhibition was due to suppression of levels of inducible nitric oxide protein rather than a direct effect on the iNOS enzyme itself. This occurred at the transcriptional level, since the compounds stabilised the LPS-induced breakdown of the NF- $\kappa \mathrm{B}$ inhibitory protein $\mathrm{I} \kappa \mathrm{B} \alpha$ and prevented nuclear translocation of NF- $\kappa \mathrm{B}$ p 65 , thereby reducing NF- $\kappa \mathrm{B}$ activity.
Thus the gingerol analogs reduced nitric oxide production via attenuation of NF- $\kappa \mathrm{B}$-mediated iNOS gene expression, providing another pathway for anti-inflammatory activity likely associated with insulin resistance.

\section{Studies on Glucose Uptake}

5.1. Ginger Extract and Gingerols Enhance Glucose Uptake in Skeletal Muscle Cells [24]. An important aspect of our work and of others is the study of the mechanisms underlying reduction of blood glucose and glucose tolerance observed in the animal models. For these studies we used in vitro models of glucose uptake and their cellular pathways in skeletal muscle cells. Under physiological conditions, the blood glucose level is strictly maintained within a narrow range, mediated by both insulin-dependent and insulinindependent mechanisms $[64,65]$. Skeletal muscle is the major site of glucose clearance in the body and accounts for over $75 \%$ of insulin-stimulated postprandial glucose disposal $[66,67]$. The rate-limiting step of glucose metabolism in skeletal muscle is glucose transport through the plasma membrane via GLUT4, one isoform of the 12-transmembrane domain sugar transporter family predominantly expressed in skeletal muscle $[68,69]$. It has been established that GLUT4 translocates from intracellular storage compartments to the cell surface in response to acute insulin stimulation or other stimuli [70]. In type 2 diabetic (T2D) patients the capacity of skeletal muscle to uptake glucose is markedly reduced due to impaired insulin signal transduction [71-73]. However, the insulin-independent pathways remain unchanged during exercise or muscle contraction [74].

Total ginger extract increased glucose uptake in L6 myotubes in a concentration-dependent manner, similar to that observed with metformin as a positive control. As mentioned earlier a ginger extract subfraction concentrated in (S)-[6]-gingerol showed enhanced glucose uptake. An example of the dose dependence of stimulation of glucose uptake by $(S)$-[6]-gingerol is shown in Figure 5. Although (S)[6]-gingerol and (S)-[8]-gingerol showed similar maximum activities, (S)-[8]-gingerol was the more potent homologue and was studied for its mechanism of glucose uptake. The concentration-dependent promotion of glucose uptake by (S)-[8]-gingerol occurred in the presence or absence of insulin, suggesting a pathway independent of insulin. (S)-[8]Gingerol, while only slightly increasing the protein level of GLUT4, substantially increased its plasma membrane surface 


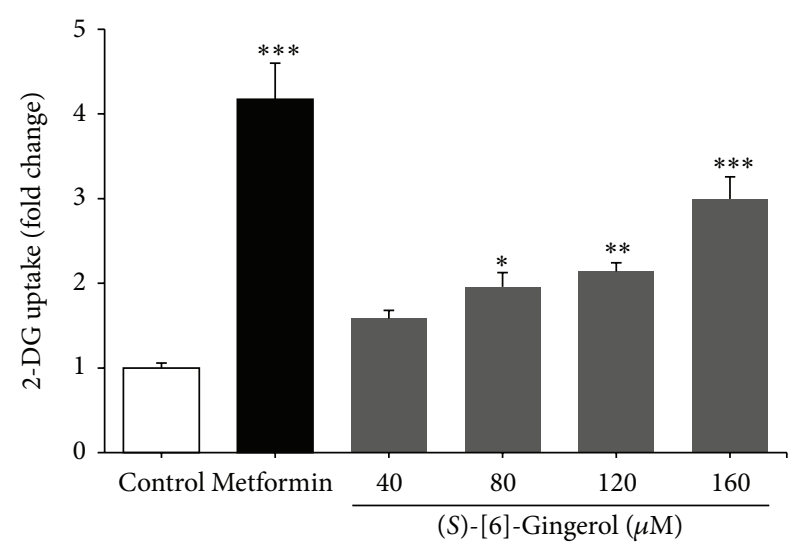

FIGURE 5: Dose dependence of (S)-[6]-gingerol enhancement of glucose uptake in L6 skeletal muscle cells. ${ }^{*} P<0.05$; ${ }^{* *} P<0.01$; ${ }^{* * *} P<0.001$ (from $[23,24]$ ).

distribution in a dose-dependent manner, as determined in L6 myotubes by measurement of the cell surface distribution by HA epitope-tagged GLUT4 imaging in L6 myotubes. We calculated based on a pharmacokinetic study in rats [75] that the concentrations of (S)-[6]-gingerol $(160 \mu \mathrm{M}$ or $0.16 \mu \mathrm{Mol} / \mathrm{mL}$ ), found to enhance glucose transport in the in vitro study, can be achieved in vivo.

\subsection{The Role of AMPK and $\mathrm{Ca}^{2+}$ in the Effect of Ginger on Glucose Uptake [76]}

5.2.1. AMPK Activation. It was not fully understood at this stage how gingerol induced GLUT4 translocation in L6 myotubes. In the normal physiological condition, GLUT4 resides in intracellular storage compartments and cycles slowly to the plasma membrane. Insulin stimulation causes GLUT4 to undergo exocytosis and relocate to the plasma membrane [77]. Recent studies showed that stimuli evoking AMP-activated protein kinase (AMPK) can induce GLUT4 translocation to the cell surface by pathways distinct from signalling pathways of insulin [78]. The next phase of our study therefore aimed to investigate the mechanism of gingerols in promoting glucose uptake in L6 skeletal muscle cells. We focused on investigating AMPK, which is known to have a key role in regulating energy fuel $[79,80]$ and is an important drug target [81]. In skeletal muscle AMPK activation in response to metabolic stress leads to a switch of cellular metabolism from anabolic to catabolic states. Acute activation of AMPK has been shown to increase glucose uptake by promoting glucose transporter (GLUT4) translocation to the plasma membrane, as well as facilitated fatty acid influx and $\beta$-oxidation [82-84]. Repetitive AMPK activation results in upregulation of numerous genes and proteins involved in energy metabolism. Activation of AMPK occurs by phosphorylation at threoninel72 (Thr172) on the loop of the catalytic domain of the $\alpha$-subunit $[85,86]$. Concomitant with its enhancement of glucose uptake (S)-[6]gingerol induced a dose- and time-dependent enhancement of threonine172 phosphorylated AMPK $\alpha$ in L6 myotubes. Consistent with this activation, phosphorylated acetyl-CoA carboxylase ( $\mathrm{p}$-ACCSerine79), one of the downstream targets of AMPK, was elevated maximally within $5 \mathrm{~min}$ and was maintained thereafter.

5.2.2. Gingerols Increase $\mathrm{Ca}^{2+}$ Signalling in Muscle Cells. (S)[6]-Gingerol was shown to increase intracellular $\mathrm{Ca}^{2+}$ concentration in a dose-dependent manner within 1 minute in L6 myotubes, although the increase appeared more gradual than that seen with carbachol as a control. Pretreatment of L6 myotubes with the intracellular $\mathrm{Ca}^{2+}$ chelator BAPTAAM abolished the stimulation of glucose uptake by (S)[6]-gingerol. The $\mathrm{Ca}^{2+} /$ calmodulin-dependent protein kinase kinase (CAMKK), which is triggered by increased intracellular $\mathrm{Ca}^{2+}$ concentration, is one of two major upstream kinases known to regulate AMPK [87-89]. We showed that (S)-[6]-gingerol-induced AMPK phosphorylation was mediated by CaMKK in L6 myotubes. Enhanced glucose uptake was also abolished by pretreatment with the CaMKK inhibitor STO609 (7-oxo-7H-benzimidazo[2, 1-a]benz[de] isoquinoline-3-carboxylic acid acetate). The increase in (S)[6]-gingerol (50-150 $\mu \mathrm{M})$ induced AMPK $\alpha$ Thr172 phosphorylation was blocked by STO609 added 30 minutes before $(S)$ [6]-gingerol treatment. These results indicated that (S)-[6]gingerol-induced AMPK $\alpha$ phosphorylation was modulated by raised intracellular $\mathrm{Ca}^{2+}$ and mediated via CaMKK.

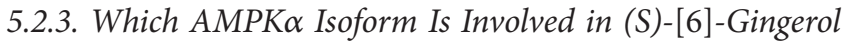
Glucose Uptake? AMPK $\alpha 1$ and AMPK $\alpha 2$, encoded by different genes [90], are considered to have different physiological roles in mediating energy homeostasis [91]. To determine which AMPK $\alpha$ isoform is involved in (S)-[6]-gingerol glucose uptake the two genes were selectively knocked down by transfecting their corresponding siRNAs. In our study, the (S)-[6]-gingerol-stimulated increase of glucose uptake required AMPK $\alpha 1$ in L6 myotubes, indicating that AMPK $\alpha 1$ was the dominant isoform involved in (S)-[6]-gingerolstimulated glucose uptake in L6 skeletal muscle cells [76].

\subsection{Effect of Ginger on AMPK and GLUT4 Expression in Rat} Skeletal Muscle. In vitro studies showed that ginger extract and its major pungent principle (S)-[6]-gingerol enhanced glucose uptake with associated activation of AMPK $\alpha$ in cultured L6 skeletal muscle cells. Here we examined the AMPK $\alpha$ Thr172 phosphorylation and the GLUT4 expression in isolated skeletal muscle tissue after ginger extract treatment for 10 weeks in the high fat, high carbohydrate (HFHC) diet fed rat model described above [31]. AMPK $\alpha$ Thr172 phosphorylation level and protein content of AMPK $\alpha$ were not significantly altered in skeletal muscle tissue of the HFHC rats. Ginger extract, however, increased AMPK protein expression by $29.0 \%$ and AMPK $\alpha$ Thr172 phosphorylation by $46.0 \%$ above the HFHC control, although the increase did not reach statistical significance. Metformin significantly increased AMPK $\alpha$ phosphorylation, consistent with its previously reported effects $[92,93]$. 


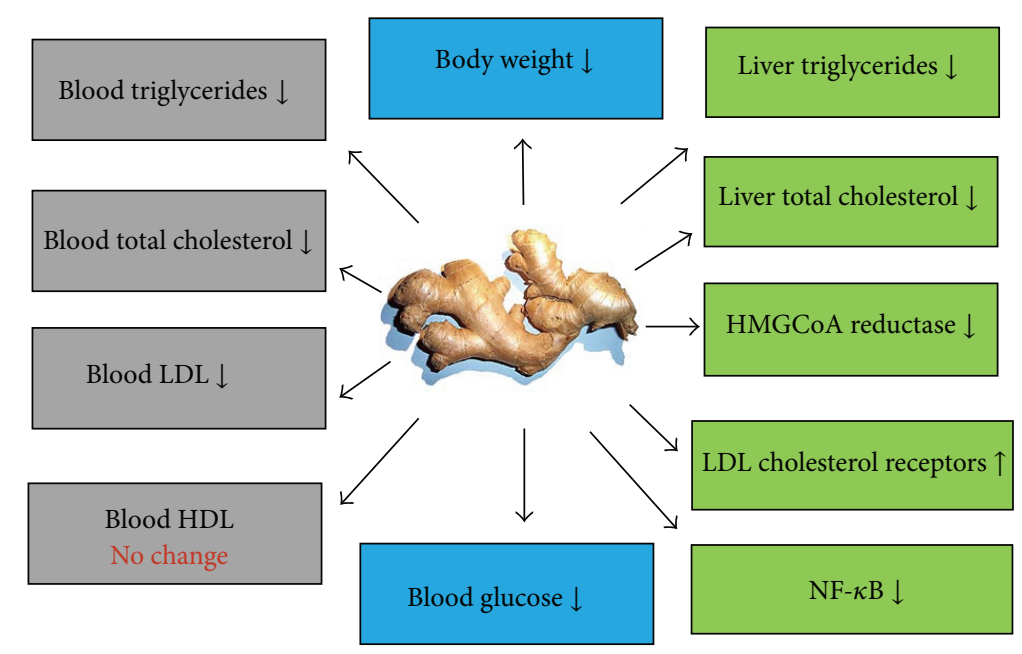

FIGURE 6: A summary of the effects of ginger from animal and in vitro studies (with thanks to Dr. Srinivas Nammi for the diagram layout).

5.4. Influence of Ginger on Peroxisome Proliferator-Activated Receptor- $\gamma$ Coactivator-1 $\alpha$ (PGC-1 $\alpha)$ and Mitochondria. We next investigated the significance of the finding that $(S)$-[6]gingerol increased AMPK $\alpha$ phosphorylation in L6 myotubes [31]. We showed that the increase in (S)-[6]-gingerol-induced AMPK $\alpha$-subunit phosphorylation in L6 skeletal muscle cells was accompanied by a time-dependent marked increment of PGC- $1 \alpha$ mRNA expression and mitochondrial content in L6 skeletal muscle cells. AMPK activation leads to enhanced energy expenditure and is strongly associated with transcriptional adaptation, including increased PGC- $1 \alpha$. PGC$1 \alpha$ is expressed at high levels in tissues active in oxidative metabolism, including skeletal muscle, heart, and brown adipose tissue, and is considered a key "master regulator" of mitochondrial biogenesis [94]. Recent clinical findings strongly indicate that downregulation of PGC- $1 \alpha$ and defects in mitochondrial function are closely associated with the pathogenesis of insulin resistance and type 2 diabetes [95, 96]. Mitochondria in insulin resistant offspring of type 2 diabetic patients were lower in density compared to control subjects and were impaired in activity [97, 98]. A similar finding was reported in the skeletal muscle of insulin resistant elderly subjects [99]. Our study showed that (S)-[6]-gingerol treatment significantly increased mRNA expression of PGC$1 \alpha$ within 5 hours in L6 myotubes and markedly increased mitochondrial content detected at a later time. From the overall results obtained, we hypothesized that the metabolic capacity of skeletal muscle is enhanced by feeding total ginger extract. These results suggest that the improvement of HFHCdiet-induced insulin resistance by ginger is likely associated with the increased capacity of energy metabolism by its major active component (S)-[6]-gingerol.

\section{Future Outlook and Perspective}

Herbal natural product medicine research can be thought to involve the science of "reverse pharmacology" [27]. While the allopathic pharmaceutical drug discovery approach starts with a new molecule (a chemical molecule isolated from a natural product or obtained by chemical synthesis) and is followed by cellular and animal studies leading to clinical investigation in phase 1-4 clinical trials, reverse pharmacology has as its base traditional knowledge of use and safety over hundreds or even thousands of years. Extensive traditional knowledge on ginger can be validated by modern pharmacological studies relevant to diabetes management, emphasising the chemical nature of ginger, its effects on parameters of hyperglycemia and hyperlipidemia underlying insulin resistance, and inflammatory responses in animal models and in vitro cell studies, as well as detailed studies of the mechanisms of the observed biological actions. However, this information alone is not sufficient to provide evidence for safety and efficacy of a natural product and requires additional investigation. Studies on the mechanism of biological effects allow greater understanding of the factors underpinning the safe use of the medicine, including interactions with other drugs or nutritional factors. If the totality of these results confirms and explains the traditional uses, a clinical study in volunteers or patients may be justified for the specific outcome being proposed. Our work on ginger has largely followed this path. In this report the studies underlying the chemical composition and biomedical actions of Zingiber officinale rhizome from our laboratory have been reviewed, with major findings summarised in Figure 6. Future developments require translation of the traditional information and pharmacological studies to clinical outcomes of proven benefit in the pandemic of diabetes and metabolic syndrome facing the developing world in particular. Some of the issues that need to be addressed are discussed in this section.

6.1. Further Clinical Studies on Ginger Are Needed. Many herbs have demonstrated antidiabetic/antihyperlipidemic effects in vitro and in animal studies in the literature. A considerable amount of information exists about the underlying mechanism of their actions, and we as well as others have reviewed this literature $[12,13]$. It is now necessary to follow up the traditional knowledge and the large amount of pharmacological investigation in well-designed clinical 
programs on these herbs and development of appropriate strategies for prevention and treatment of diabetes and prediabetic and cardiovascular conditions. Such studies will be best undertaken by international cooperation and targeted, appropriately funded programs.

Despite the large number of in vitro and animal studies performed on Zingiber officinale extracts, surprisingly few clinical studies are available in the chronic metabolic condition of prediabetes, diabetes, and hyperlipidemia of cardiovascular diseases. This lack of clinical data is also true for most herbal medicine investigation and is the result of a number of factors, including the difficulty of funding such research due to limited commercial support and the complexity of the herbal and natural product materials. In the case of ginger extract the limited clinical studies done were often contradictory and difficult to interpret. In one study after consumption of $3 \mathrm{~g}$ of dry ginger powder in divided dose for 30 days, significant reduction in blood glucose, triglyceride, total cholesterol, LDL, and VLDL cholesterol was observed in diabetic patients [100]. A number of new clinical studies have been published recently. In a randomized double-blind placebo controlled trial, 64 patients with type 2 diabetes were assigned to ginger or placebo groups (receiving $2 \mathrm{~g} /$ day of each). Various parameters were determined before and after 2 months of intervention. Ginger supplementation significantly lowered the levels of insulin, LDL-C, triglyceride, and the HOMA index (3.9 versus 4.5) and increased the insulin-sensitivity check index (QUICKI) in comparison to the control group, while there were no significant changes in FPG, total cholesterol, HDL-C, and HbAlc [101]. In a double-blinded, placebo-controlled clinical trial, 70 type 2 diabetic patients consumed $1600 \mathrm{mg}$ ginger versus $1600 \mathrm{mg}$ wheat flour placebo daily for 12 weeks. Ginger reduced fasting plasma glucose, HbA1C, insulin, HOMA, triglyceride, total cholesterol, CRP, and PGE2 significantly compared with the placebo group; there were no significant differences in HDL, LDL, and TNFa between the two groups [102]. In another study $3 \mathrm{~g}$ of dry ginger powder given to diabetic patients for 3 months and compared to a control showed significant effects at the end of the treatment on fasting blood glucose (10.5\% decrease), HbAlc, and the quantitative insulin sensitivity check index (QUICKI). Whilst both treatment groups showed a decrease in insulin resistance index (HOMAR-IR), these were not different between placebo and treatment group and no significant effects were seen on fasting insulin, $\beta$-cell function $(\beta \%)$, and insulin sensitivity $(S \%)[103]$. By contrast other studies failed to show a positive effect in diabetes. In a study by Bordia et al. [104] the effect of ginger and fenugreek on blood sugar and lipid concentration was investigated in patients with coronary artery disease (CAD) and diabetic patients (with or without CAD). Consumption of $4 \mathrm{~g}$ ginger powder for 3 months was not effective in controlling lipids or blood sugar.

Discrepancy of results from clinical studies may be attributed to a number of factors. Most studies fail to provide a chemical composition profile of the sample used in the clinical trial, and ginger preparations may vary enormously in their composition, depending on the extract preparation method, the origin of the ginger, and storage duration and conditions $[105,106]$. Variations are found in the content of gingerols and their relative distributions between [6]-, [8]-, [10]-, and [12]-(S)-gingerols, the content of shogaols (which varies greatly between fresh and stored samples), and other components such as sesquiterpenes and volatile oils, which may all be significant to various extents for the final biological effect. Differences in the study protocols may also contribute to different clinical results, especially the length of treatment, inclusion, and exclusion criteria and power of the studies. For ethics reasons most studies in diabetics are carried out without restriction of the normal diabetic medication, so that the extracts are often evaluated on top of this medication. Finally, it is possible that pharmacodynamic and pharmacokinetic differences between rodent animals and humans influence differences in the effectiveness of ginger observed between human trials and animal studies. This may reflect differences in metabolism and bioavailability of components between animals and humans. Pharmacokinetic studies in rats have shown rapid absorption of [6]-gingerol following oral administration of a ginger extract (containing $53 \%$ of [6]-gingerol), reaching a maximum plasma concentration of $4.24 \mu \mathrm{g} / \mathrm{mL}$ after 10 -minute postdosing and then declining with time, with an elimination half-time at the terminal phase of $1.77 \mathrm{~h}$ and apparent total body clearance of $40.8 \mathrm{l} / \mathrm{h}$. Maximum concentrations of [6]-gingerol were seen in the majority of tissues examined at 30 minutes, with the highest values being $534 \mu \mathrm{g} / \mathrm{g}$ in stomach followed by $294 \mu \mathrm{g} / \mathrm{g}$ in small intestine [75]. By contrast, when human volunteers took $100 \mathrm{mg}$ to $2 \mathrm{~g}$ of ginger extract, there were no free forms of gingerols and shogaol detected using standard assays in plasma, but these were found as the glucuronide and sulphate conjugates [107]. However, with a more sensitive technique, free forms of [10]-gingerol $(9.5 \mathrm{ng} / \mathrm{mL})$ and [6]shogaol $(13.6 \mathrm{ng} / \mathrm{mL})$ were observed, as well as glucuronide and sulphate metabolites of [6]-, [8]-, and [10]-gingerol and [6]-shogaol, with half-lives of the free compounds and their metabolites of $1-3 \mathrm{~h}$ in human plasma [108]. It can thus be concluded that gingerols and shogaols are rapidly absorbed and accumulate in a number of tissues in animals and are extensively metabolised. In humans [6]-gingerol is found only as the glucuronide and sulphate at peak levels of $0.47 \mu \mathrm{g} / \mathrm{mL}$. There is of course limited ability to study levels of free gingerols and shogaols or their metabolites in relevant tissues in humans. To demonstrate effectiveness of ginger further pharmacodynamic and pharmacokinetic studies in humans will be necessary, and achieving maximum effectiveness will likely require modern formulation of the ginger extracts to maximise absorption and optimum tissue distribution of free forms of gingerols and shogaols or other active metabolites still to be determined. Clearly more clinical studies with appropriate design and on well-defined ginger preparations are required to evaluate the effectiveness and the pattern of effects of ginger in human subjects in the prevention and/or treatment of diabetes and related metabolic disorders.

6.2. New Drug Development from Ginger. Another important direction in natural product research is the use of the 
chemical template of the natural product for the development of new molecules as pharmaceutical agents from its known traditional use. Current drug therapy of diabetes and especially prediabetic metabolic syndrome is limited by effectiveness and side effects of existing medications, and new drugs are clearly needed. There are many examples where natural product research on plant materials has led to the development of new drugs [109], and it is estimated that around $50 \%$ of currently used drugs are natural products or derivatives of natural products. In our work we have investigated the effectiveness of the major component of Zingiber officinale, (S)-[6]-gingerol, as summarised above. We also undertook a program to develop more potent and more stable analogs of gingerols as potential new drug molecules [110]. Two chemically stable derivatives of gingerols were found to be about an order of magnitude greater in potency than [6]-gingerol in their blocking of iNOS production [63]. A range of synthetic derivatives were made in an attempt to increase potency and selectivity. Whilst the synthetic derivatives showed considerable enhancement of potency in animal models of inflammation, the decrease in the therapeutic safety index from the natural products remained a challenge ([111], [112] Roufogalis et al., unpublished results 2003). Additional studies are therefore needed not only to enhance the potency of compounds based on the gingerol template, but also to increase selectivity and the therapeutic index of effectiveness and safety.

6.3. Identifying the Binding Sites for Ginger Components. Whilst many studies on natural products have in recent times identified the cellular pathways and gene and protein modifications involved in various disease models, few studies have identified receptor sites of the major active constituents. Whilst transient receptor potential cation channel subfamily V member 1 (TRPV1), also known as the capsaicin receptor and the vanilloid receptor 1 , has been identified as a target of gingerols [57], it has been more difficult to determine if these or other related or unrelated receptors are important in the mode of action of gingerols in enhancing glucose uptake in muscle and in inflammation and other actions associated with insulin resistance. Such studies will require the application of gene-knockout/knockdown technology, where cell receptors are functionally removed and the effects of added ginger extracts or active components are reinvestigated.

6.4. The Multiple Targets of Ginger Action. Whilst we and others have investigated the effects of ginger extracts in a variety of cell systems and in animal models, the action of herbal medicines is often characterised by biological effects at multiple targets arising from multiple components. Thus it is difficult to determine with certainty which pathways are of greatest relevance in the actions of Zingiber officinale in diabetes and prediabetic states. One possible way to achieve this is to compare the potency (i.e., effective dose or concentration) of individual components relevant to a measured effect, on the assumption that therapeutic efficacy is more likely to correspond to those effects which demonstrate the highest potency that occurs at the lowest doses. However, this is bound to be an oversimplification, since pharmacokinetic studies are needed to determine concentrations in different organs and cell compartments, whilst the optimal therapeutic effects may be contributed by multiple activities. Other mechanisms of Zingiber officinale and its components include upregulation of adiponectin by 6-shogaol and 6-gingerol and PPAR- $\gamma$ agonistic activity of 6-shogaol (but not 6-gingerol) [113], activation of hepatic cholesterol- $7 \alpha$-hydroxylase to stimulate the conversion of hepatic cholesterol to bile acids $[114,115]$, increase in the faecal excretion of cholesterol and possible block of absorption of cholesterol in the gut [116], and inhibition of cellular cholesterol biosynthesis described in an apolipoprotein E-deficient mouse [117]. Other possible effects are related to its COX2 actions in diabetic chronic inflammation and effects on carbohydrate through inhibition of hepatic phosphorylase (to prevent the glycogenolysis in hepatic cell) and increase of enzyme activities contributing to progression of glycogenesis and inhibition of the activity of hepatic glucose-6-phosphatase (thereby decreasing glucose phosphorylation and contributing to lowering blood glucose) [40]. Additional mechanisms of ginger action were provided in our recent review [26]. Thus, the molecular mechanisms responsible for the observed effects of ginger on lipid and glucose regulation are likely due to both single and multiple effects of its active components at various potential sites of action.

\section{Final Summary and Conclusion}

Many animal and cell biological studies have been conducted on ginger (Zingiber officinale), a traditional medicine used in inflammation and related conditions. Studies conducted in our laboratory over a number of years have contributed to an understanding of the mechanism underlying the beneficial effects of ginger in type 2 diabetes and the metabolic syndrome. A number of clinical trials have shown positive effects on both lipid and blood glucose control in type 2 diabetes, but further studies on ginger preparations of defined chemical composition and their specific mechanisms are required.

\section{Conflict of Interests}

The author declares that there is no conflict of interests regarding the publication of this paper.

\section{Acknowledgments}

The author would like to acknowledge and thank many people who have worked on the study of ginger in his laboratory and have been responsible for the studies described in this paper. These include former postdoctoral fellows (Srinivas Nammi, X-H (Lani) Li, and Vadim Dedov), research fellows (Van Hoan Tran, Fugen Aktan), Ph.D. students (Yiming Li, Bhavani Prasad Kota, Nooshin Koolaji, Effie Tjendraputra, Moon Sun (Sunny) Kim, MK (Min) Song, and TH-W (Tom) Huang), collaborators (Qian (George) Li, Kristine McGrath, and Alison Heather), and academic colleagues (Professors Colin Duke, Sigrun Chrubasik, and Alaina Ammit). The 
author also thanks the granting agencies that made this work possible (ARC Linkage, National Institute of Complementary Medicine (NICM), and the NHMRC).

\section{References}

[1] M. Hirst, IDF Diabetes Atlas, International Diabetes Federation, 6th edition, 2013.

[2] N. H. Cho, IDF Diabetes Atlas, International Diabetes Federation, 6th edition, 2013.

[3] K. G. M. M. Alberti and P. Z. Zimmet, "Definition, diagnosis and classification of diabetes mellitus and its complications. Part 1: diagnosis and classification of diabetes mellitus provisional report of a WHO consultation," Diabetic Medicine, vol. 15, no. 7, pp. 539-553, 1998.

[4] M. Parillo and G. Riccardi, "Diet composition and the risk of type 2 diabetes: epidemiological and clinical evidence," British Journal of Nutrition, vol. 92, no. 1, pp. 7-19, 2004.

[5] K. K. Ray, S. R. K. Seshasai, S. Wijesuriya et al., "Effect of intensive control of glucose on cardiovascular outcomes and death in patients with diabetes mellitus: a meta-analysis of randomised controlled trials," The Lancet, vol. 373, no. 9677, pp. 1765-1772, 2009.

[6] R. R. Holman, S. K. Paul, M. A. Bethel, D. R. Matthews, and H. A. W. Neil, "10-Year follow-up of intensive glucose control in type 2 diabetes," The New England Journal of Medicine, vol. 359, no. 15, pp. 1577-1589, 2008.

[7] F. Ismail-Beigi, T. Craven, M. A. Banerji et al., "Effect of intensive treatment of hyperglycaemia on microvascular outcomes in type 2 diabetes: an analysis of the ACCORD randomised trial," The Lancet, vol. 376, no. 9739, pp. 419-430, 2010.

[8] Y. Arad, D. Newstein, F. Cadet, M. Roth, and A. D. Guerci, "Association of multiple risk factors and insulin resistance with increased prevalence of asymptomatic coronary artery disease by an electron-beam computed tomographic study," Arteriosclerosis, Thrombosis, and Vascular Biology, vol. 21, no. 12, pp. 20512058, 2001.

[9] K. Tayama, T. Inukai, and Y. Shimomura, "Preperitoneal fat deposition estimated by ultrasonography in patients with noninsulin-dependent diabetes mellitus," Diabetes Research and Clinical Practice, vol. 43, no. 1, pp. 49-58, 1999.

[10] I. R. Wanless and J. S. Lentz, "Fatty liver hepatitis (steatohepatitis) and obesity: an autopsy study with analysis of risk factors," Hepatology, vol. 12, no. 5, pp. 1106-1110, 1990.

[11] Executive Summary, IDF Diabetes Atlas, International Diabetes Federation, 6th edition, 2013.

[12] E. A. Omara, A. Kam, A. Alqahtania et al., "Herbal medicines and nutraceuticals for diabetic vascular complications: mechanisms of action and bioactive phytochemicals," Current Pharmaceutical Design, vol. 16, no. 34, pp. 3776-3807, 2010.

[13] T. H. Huang, B. P. Kota, V. Razmovski, and B. D. Roufogalis, "Herbal or natural medicines as modulators of peroxisome proliferator-activated receptors and related nuclear receptors for therapy of metabolic syndrome," Journal of Basic and Clinical Pharmacology and Toxicology, vol. 96, no. 1, pp. 3-14, 2005.

[14] C. J. Bailley and C. Day, "Metformin: its botanical background," Practical Diabetes International, vol. 21, pp. 115-117, 2004.

[15] D. Lender and S. K. Sysko, "The metabolic syndrome and cardiometabolic risk: scope of the problem and current standard of care," Pharmacotherapy, vol. 26, no. 5, pp. 3S-12S, 2006.
[16] B. White, “Ginger: an overview," The American Family Physician, vol. 75, no. 11, pp. 1689-1691, 2007.

[17] W. Wang and Z. Wang, "Studies of commonly used traditional medicine-ginger," Zhongguo Zhongyao Zazhi, vol. 30, no. 20, pp. 1569-1573, 2005.

[18] S. Chrubasik, M. H. Pittler, and B. D. Roufogalis, "Zingiberis rhizoma: a comprehensive review on the ginger effect and efficacy profiles," Phytomedicine, vol. 12, no. 9, pp. 684-701, 2005.

[19] H. Zhou, L. Wei, and H. Lei, "Analysis of essential oil from rhizoma Zingiberis by GC-MS," Zhongguo Zhong Yao Za Zhi, vol. 23, no. 4, pp. 234-256, 1998.

[20] W. Blaschek, R. Hansel, L. Keller, J. Reichling, H. Rimpler, and G. Schneider, in Hagers Handbuch der Pharmazeutischen Praxis, L.-Z. Drogen, Ed., pp. 837-858, Springer, Berlin, Germany, 1998.

[21] S. Bhattarai, H. van Tran, and C. C. Duke, "The stability of gingerol and shogaol in aqueous solutions," Journal of Pharmaceutical Sciences, vol. 90, no. 10, pp. 1658-1664, 2001.

[22] Y. Li, A study on the enhancement of glucose uptake by gingerols of Zingiber officinale via AMPK activation in skeletal muscle [Ph.D. thesis], University of Sydney, 2013.

[23] X. Li, K. C. Y. McGrath, S. Nammi, A. K. Heather, and B. D. Roufogalis, "Attenuation of liver pro-inflammatory responses by Zingiber officinale via inhibition of NF-kappa B activation in high-fat diet-fed rats," Basic and Clinical Pharmacology and Toxicology, vol. 110, no. 3, pp. 238-244, 2012.

[24] Y. Li, V. H. Tran, C. C. Duke, and B. D. Roufogalis, “Gingerols of zingiber officinale enhance glucose uptake by increasing cell surface GLUT4 in cultured L6 myotubes," Planta Medica, vol. 78, no. 14, pp. 1549-1555, 2012.

[25] X.-H. Li, K. McGrath, A. K. Heather, and B. D. Roufogalis, "Ethanolic extract of zingiber officinale suppresses hepatic NF kappa B," in Proceedings of the OzBio Conference, Melbourne, VIC, Australia, 2010.

[26] Y. Li, V. H. Tran, C. C. Duke, and B. D. Roufogalis, "Preventive and protective properties of Zingiber officinale (Ginger) in diabetes mellitus, diabetic complications, and associated lipid and other metabolic disorders: a brief review," Evidence-Based Complementary and Alternative Medicine, vol. 2012, Article ID 516870, 10 pages, 2012.

[27] B. Patwardhan and A. D. B. Vaidya, "Natural products drug discovery: accelerating the clinical candidate development using reverse pharmacology approaches," Indian Journal of Experimental Biology, vol. 48, no. 3, pp. 220-227, 2010.

[28] S. Nammi, S. Sreemantula, and B. D. Roufogalis, "Protective effects of ethanolic extract of $Z$ ingiber officinale rhizome on the development of metabolic syndrome in high-fat diet-fed rats," Basic and Clinical Pharmacology and Toxicology, vol. 104, no. 5, pp. 366-373, 2009.

[29] S. Nammi, M. S. Kim, N. S. Gavande, G. Q. Li, and B. D. Roufogalis, "Regulation of low-density lipoprotein receptor and 3-hydroxy-3- methylglutaryl coenzyme A reductase expression by zingiber officinale in the liver of high-fat diet-fed rats," Basic and Clinical Pharmacology and Toxicology, vol. 106, no. 5, pp. 389-395, 2010.

[30] S. D. J. M. Niemeijer-Kanters, J. D. Banga, and D. W. Erkelens, "Lipid-lowering therapy in diabetes mellitus," Netherlands Journal of Medicine, vol. 58, no. 5, pp. 214-222, 2001.

[31] Y. Li, V. H. Tran, B. P. Kota, S. Nammi, C. C. Duke, and B. D. Roufogalis, "Preventative effect of Zingiber officinale on insulin resistance in a high-fat, high-carbohydrate diet-fed rat model and its mechanism of action," Basic \& Clinical Pharmacology \& Toxicology, vol. 115, no. 2, pp. 209-215, 2014. 
[32] P. L. Lutsey, L. M. Steffen, and J. Stevens, "Dietary intake and the development of the metabolic syndrome: the atherosclerosis risk in communities study," Circulation, vol. 117, no. 6, pp. 754761, 2008.

[33] M. J. Hill, D. Metcalfe, and P. G. McTernan, "Obesity and diabetes: lipids, "nowhere to run to'”' Clinical Science, vol. 116, no. 2, pp. 113-123, 2009.

[34] I. Sluijs, Y. T. van der Schouw, D. L. van der A et al., "Carbohydrate quantity and quality and risk of type 2 diabetes in the European Prospective Investigation into Cancer and NutritionNetherlands (EPIC-NL) study," The American Journal of Clinical Nutrition, vol. 92, no. 4, pp. 905-911, 2010.

[35] H. Basciano, L. Federico, and K. Adeli, "Fructose, insulin resistance, and metabolic dyslipidemia," Nutrition and Metabolism, vol. 2, article 5, 2005.

[36] L. H. Storlien, L. A. Baur, A. D. Kriketos et al., "Dietary fats and insulin action," Diabetologia, vol. 39, no. 6, pp. 621-631, 1996.

[37] G. S. Hotamisligil, "Inflammation and metabolic disorders," Nature, vol. 444, no. 7121, pp. 860-867, 2006.

[38] P. Marceau, S. Biron, F.-S. Hould et al., "Liver pathology and the metabolic syndrome $\mathrm{X}$ in severe obesity," The Journal of Clinical Endocrinology \& Metabolism, vol. 84, no. 5, pp. 1513-1517, 1999.

[39] M. Afzal, D. Al-Hadidi, M. Menon, J. Pesek, and M. S. I. Dhami, "Ginger: an ethnomedical, chemical and pharmacological review," Drug Metabolism and Drug Interactions, vol. 18, no. 3-4, pp. 159-190, 2001.

[40] R. Grzanna, L. Lindmark, and C. G. Frondoza, "Gingeran herbal medicinal product with broad anti-inflammatory actions," Journal of Medicinal Food, vol. 8, no. 2, pp. 125-132, 2005.

[41] L. Lindmark, "An in vitro screening assay for inhibitors of proinflammatory mediators in herbal extracts using human synoviocyte cultures," In Vitro Cellular \& Developmental BiologyAnimal, vol. 40, pp. 95-101, 2004.

[42] H. W. Jung, C. Yoon, K. M. Park, H. S. Han, and Y. Park, "Hexane fraction of Zingiberis Rhizoma Crudus extract inhibits the production of nitric oxide and proinflammatory cytokines in LPS-stimulated BV2 microglial cells via the NF-kappaB pathway," Food and Chemical Toxicology, vol. 47, no. 6, pp. 11901197, 2009.

[43] D. Cai, M. Yuan, D. F. Frantz et al., "Local and systemic insulin resistance resulting from hepatic activation of IKK- $\beta$ and NF«B," Nature Medicine, vol. 11, no. 2, pp. 183-190, 2005.

[44] T. A. Pearson, G. A. Mensah, R. W. Alexander et al., "Markers of inflammation and cardiovascular disease: application to clinical and public health practice: A statement for healthcare professionals from the centers for disease control and prevention and the American Heart Association," Circulation, vol. 107, no. 3, pp. 499-511, 2003.

[45] S. Ghosh, M. J. May, and E. B. Kopp, "NF- $\kappa$ B and rel proteins: evolutionarily conserved mediators of immune responses," Annual Review of Immunology, vol. 16, pp. 225-260, 1998.

[46] X. H. Li, K. C. Y. McGrath, V. H. Tran et al., "Attenuation of Pro-Inflammatory Responses by [6]-S-gingerol via Inhibition of ROS/NF-kappa B/COX2 Activation in HuH7 cells," EvidenceBased Complementary and Alternative Medicine, vol. 2013, Article ID 146142, 8 pages, 2013.

[47] C. Frondoza, A. G Sohrabi, A. Polotsky, P. V. Phan, D. S. Hungerford, and L. Lindmark, "An in vitro screening assay for inhibitors of proinflammatory mediators in herbal extracts using human synoviocyte cultures," In Vitro Cellular \& Developmental Biology, vol. 40, no. 3-4, pp. 95-101, 2004.
[48] J. W. Christman, L. H. Lancaster, and T. S. Blackwell, "Nuclear factor $\kappa \mathrm{B}$ : a pivotal role in the systemic inflammatory response syndrome and new target for therapy," Intensive Care Medicine, vol. 24, no. 11, pp. 1131-1138, 1998.

[49] S. A. Abd-El-Aleem, M. W. J. Ferguson, I. Appleton, A. Bhowmick, C. N. McCollum, and G. W. Ireland, "Expression of cyclooxytenase isoforms in normal human skin and chronic venous ulcers," Journal of Pathology, vol. 195, no. 5, pp. 616-623, 2001.

[50] A. A. Oyagbemi, A. B. Saba, and O. I. Azeez, "Molecular targets of [6]-gingerol: its potential roles in cancer chemoprevention," BioFactors, vol. 36, no. 3, pp. 169-178, 2010.

[51] S. Tripathi, K. G. Maier, D. Bruch, and D. S. Kittur, "Effect of 6-gingerol on pro-inflammatory cytokine production and costimulatory molecule expression in murine peritoneal macrophages," Journal of Surgical Research, vol. 138, no. 2, pp. 209213, 2007

[52] C. Lee, G. H. Park, C. Kim, and J. Jang, "[6]-Gingerol attenuates $\beta$-amyloid-induced oxidative cell death via fortifying cellular antioxidant defense system," Food and Chemical Toxicology, vol. 49, no. 6, pp. 1261-1269, 2011.

[53] E. Tjendraputra, V. H. Tran, D. Liu-Brennan, B. D. Roufogalis, and C. C. Duke, "Effect of ginger constituents and synthetic analogues on cyclooxygenase-2 enzyme in intact cells," Bioorganic Chemistry, vol. 29, no. 3, pp. 156-163, 2001.

[54] K. C. Y. McGrath, X. H. Li, R. Puranik et al., "Role of $3 \beta$ hydroxysteroid- $\Delta 24$ reductase in mediating antiinflammatory effects of high-density lipoproteins in endothelial cells," Arteriosclerosis, Thrombosis, and Vascular Biology, vol. 29, no. 6, pp. 877-882, 2009.

[55] K. A. Roebuck, "Oxidant stress regulation of IL-8 and ICAM-1 gene expression: differential activation and binding of the transcription factors AP-1 and NF-kappaB (Review)," International Journal of Molecular Medicine, vol. 4, no. 3, pp. 223-230, 1999.

[56] X. H. Li, K. C. Y. McGrath, V. H. Tran et al., "Identification of a calcium signalling pathway of S-[6]-gingerol in $\mathrm{HuH}-7$ cells," Evidence-Based Complementary and Alternative Medicine, vol. 2013, Article ID 951758, 7 pages, 2013.

[57] V. N. Dedov, V. H. Tran, C. C. Duke et al., "Gingerols: a novel class of vanilloid receptor (VR1) agonists," British Journal of Pharmacology, vol. 137, no. 6, pp. 793-798, 2002.

[58] C. S. J. Walpole, R. Wrigglesworth, S. Bevan et al., "Analogues of capsaicin with agonist activity as novel analgesic agents; structure-activity studies. 1. The aromatic "A-region"', Journal of Medicinal Chemistry, vol. 36, no. 16, pp. 2362-2372, 1993.

[59] M. F. Leite and M. Nathanson, "Calcium signaling in the hepatocyte," in The Liver: Biology and Pathobiology, pp. 537-554, Lippincott Williams \& Wilkins, Philadelphia, Pa, USA, 2001.

[60] C. J. Dixon, P. J. White, J. F. Hall, S. Kingston, and M. R. Boarder, "Regulation of human hepatocytes by $\mathrm{P} 2 \mathrm{Y}$ receptors: control of glycogen phosphorylase, $\mathrm{Ca} 2+$, and mitogen-activated protein kinases," Journal of Pharmacology and Experimental Therapeutics, vol. 313, no. 3, pp. 1305-1313, 2005.

[61] M. Karin and A. Lin, "NF- $\kappa$ B at the crossroads of life and death," Nature Immunology, vol. 3, no. 3, pp. 221-227, 2002.

[62] S. Shishodia and B. B. Aggarwal, "Nuclear factor- $\kappa$ B activation: a question of life or death," Journal of Biochemistry and Molecular Biology, vol. 35, no. 1, pp. 28-40, 2002.

[63] F. Aktan, S. Henness, V. H. Tran, C. C. Duke, B. D. Roufogalis, and A. J. Ammit, "Gingerol metabolite and a synthetic analogue Capsarol inhibit macrophage NF- $\kappa$ B-mediated iNOS 
gene expression and enzyme activity," Planta Medica, vol. 72, no. 8, pp. 727-734, 2006.

[64] G. Pacini, K. Thomaseth, and B. Ahrén, "Contribution to glucose tolerance of insulin-independent vs. insulin-dependent mechanisms in mice," The American Journal of PhysiologyEndocrinology and Metabolism, vol. 281, no. 4, pp. E693-E703, 2001.

[65] C. L. Yun and J. R. Zierath, "AMP-activated protein kinase signaling in metabolic regulation," Journal of Clinical Investigation, vol. 116, no. 7, pp. 1776-1783, 2006.

[66] R. A. DeFronzo, R. Gunnarsson, O. Bjorkman, M. Olsson, and J. Wahren, "Effects of insulin on peripheral and splanchnic glucose metabolism in noninsulin-dependent (type II) diabetes mellitus," The Journal of Clinical Investigation, vol. 76, no. 1, pp. 149-155, 1985.

[67] A. D. Baron, G. Brechtel, P. Wallace, and S. V. Edelman, "Rates and tissue sites of non-insulin- and insulin-mediated glucose uptake in humans," The American Journal of PhysiologyEndocrinology and Metabolism, vol. 255, pp. E769-E774, 1988.

[68] K. Kubo and J. E. Foley, "Rate-limiting steps for insulinmediated glucose uptake into perfused rat hindlimb," The American Journal of Physiology-Endocrinology and Metabolism, vol. 250, no. 1, pp. E100-E102, 1986.

[69] L. M. Perriott, T. Kono, R. R. Whitesell et al., "Glucose uptake and metabolism by cultured human skeletal muscle cells: ratelimiting steps," The American Journal of Physiology: Endocrinology and Metabolism, vol. 281, no. 1, pp. E72-E80, 2001.

[70] M. Larance, G. Ramm, and D. E. James, "The GLUT4 code," Molecular Endocrinology, vol. 22, no. 2, pp. 226-233, 2008.

[71] A. Krook, M. Björnholm, D. Galuska et al., "Characterization of signal transduction and glucose transport in skeletal muscle from type 2 diabetic patients," Diabetes, vol. 49, no. 2, pp. 284$292,2000$.

[72] W. T. Garvey, L. Maianu, J. Zhu, G. Brechtel-Hook, P. Wallace, and A. D. Baron, "Evidence for defects in the trafficking and translocation of GLUT4 glucose transporters in skeletal muscle as a cause of human insulin resistance," Journal of Clinical Investigation, vol. 101, no. 11, pp. 2377-2386, 1998.

[73] G. W. Cline, K. F. Petersen, M. Krssak et al., "Impaired glucose transport as a cause of decreased insulin-stimulated muscle glycogen synthesis in type 2 diabetes," The New England Journal of Medicine, vol. 341, no. 4, pp. 240-246, 1999.

[74] N. Musi, N. Fujii, M. F. Hirshman et al., "AMP-activated protein kinase (AMPK) is activated in muscle of subjects with type 2 diabetes during exercise," Diabetes, vol. 50, no. 5, pp. 921-927, 2001.

[75] S.-Z. Jiang, N.-S. Wang, and S.-Q. Mi, "Plasma pharmacokinetics and tissue distribution of [6]-gingerol in rats," Biopharmaceutics \& Drug Disposition, vol. 29, no. 9, pp. 529-537, 2008.

[76] Y. Li, V. H. Tran, N. Koolaji, C. C. Duke, and B. D. Roufogalis, "(S)-[6]-Gingerol enhances glucose uptake in L6 myotubes by activation of AMPK in response to $\left[\mathrm{Ca}^{2+}\right] \mathrm{i}$," Journal of Pharmacy and Pharmaceutical Sciences, vol. 16, no. 2, pp. 304312, 2013.

[77] J. A. Lopez, J. G. Burchfield, D. H. Blair et al., "Identification of a distal GLUT4 trafficking event controlled by actin polymerization," Molecular Biology of the Cell, vol. 20, no. 17, pp. 3918-3929, 2009.

[78] I. Kojima and H. Shibata, "Microtubule disruption with BAPTA and dimethyl BAPTA by a calcium chelation-independent mechanism in 3T3-L1 adipocytes," Endocrine Journal, vol. 2, pp. 235-243, 2009.
[79] R. Lage, C. Diéguez, A. Vidal-Puig, and M. López, "AMPK: a metabolic gauge regulating whole-body energy homeostasis," Trends in Molecular Medicine, vol. 14, no. 12, pp. 539-549, 2008.

[80] C. A. Witczak, C. G. Sharoff, and L. J. Goodyear, "AMP-activated protein kinase in skeletal muscle: from structure and localization to its role as a master regulator of cellular metabolism," Cellular and Molecular Life Sciences, vol. 65, no. 23, pp. 37373755, 2008.

[81] A. Gruzman, G. Babai, and S. Sasson, "Adenosine monophosphate-activated protein kinase (AMPK) as a new target for antidiabetic drugs: a review on metabolic, pharmacological and chemical considerations," Review of Diabetic Studies, vol. 6, no. 1, pp. 13-36, 2009.

[82] G. F. Merrill, E. J. Kurth, B. B. Rasmussen, and W. W. Winder, "Influence of malonyl-CoA and palmitate concentration on rate of palmitate oxidation in rat muscle," Journal of Applied Physiology, vol. 85, no. 5, pp. 1909-1914, 1998.

[83] G. F. Merrill, E. J. Kurth, D. G. Hardie, and W. W. Winder, "AICA riboside increases AMP-activated protein kinase, fatty acid oxidation, and glucose uptake in rat muscle," The American Journal of Physiology_Endocrinology and Metabolism, vol. 273, no. 6, part 1, pp. E1107-E1112, 1997.

[84] E. J. Kurth-Kraczek, M. F. Hirshman, L. J. Goodyear, and W. W. Winder, “5' AMP-activated protein kinase activation causes GLUT4 translocation in skeletal muscle," Diabetes, vol. 48, no. 8, pp. 1667-1671, 1999.

[85] S. A. Hawley, M. Davison, A. Woods et al., "Characterization of the AMP-activated protein kinase kinase from rat liver and identification of threonine 172 as the major site at which it phosphorylates AMP-activated protein kinase," Journal of Biological Chemistry, vol. 271, no. 44, pp. 27879-27887, 1996.

[86] S. C. Stein, A. Woods, N. A. Jones, M. D. Davison, and D. Cabling, "The regulation of AMP-activated protein kinase by phosphorylation," Biochemical Journal, vol. 345 , no. 3, pp. 437$443,2000$.

[87] S. A. Hawley, M. A. Selbert, E. G. Goldstein, A. M. Edelman, D. Carling, and D. G. Hardie, "5/-AMP activates the AMPactivated protein kinase cascade, and $\mathrm{Ca}^{2+} /$ calmodulin activates the calmodulin-dependent protein kinase I cascade, via three independent mechanisms," The Journal of Biological Chemistry, vol. 270, no. 45, pp. 27186-27191, 1995.

[88] A. Woods, S. R. Johnstone, K. Dickerson et al., "LKB1 is the upstream kinase in the AMP-activated protein kinase cascade," Current Biology, vol. 13, no. 22, pp. 2004-2008, 2003.

[89] M. Momcilovic, S. Hong, and M. Carlson, "Mammalian TAK1 activates Snfl protein kinase in yeast and phosphorylates AMPactivated protein kinase in vitro," Journal of Biological Chemistry, vol. 281, no. 35, pp. 25336-25343, 2006.

[90] A. Woods, I. Salt, J. Scott, D. G. Hardie, and D. Carling, "The $\alpha 1$ and $\alpha 2$ isoforms of the AMP-activated protein kinase have similar activities in rat liver but exhibit differences in substrate specificity in vitro," FEBS Letters, vol. 397, no. 2-3, pp. 347-351, 1996.

[91] I. Salt, J. W. Celler, S. A. Hawley et al., "AMP-activated protein kinase: greater AMP dependence, and preferential nuclear localization, of complexes containing the $\alpha 2$ isoform," Biochemical Journal, vol. 334, no. 1, pp. 177-187, 1998.

[92] N. Ruderman and M. Prentki, "AMP kinase and malonyl-CoA: targets for therapy of the metabolic syndrome," Nature Reviews Drug Discovery, vol. 3, no. 4, pp. 340-351, 2004. 
[93] J. An, D. M. Muoio, M. Shiota et al., "Hepatic expression of malonyl-CoA decarboxylase reverses muscle, liver and wholeanimal insulin resistance," Nature Medicine, vol. 10, no. 3, pp. 268-274, 2004.

[94] B. B. Kahn, T. Alquier, D. Carling, and D. G. Hardie, "AMPactivated protein kinase: ancient energy gauge provides clues to modern understanding of metabolism," Cell Metabolism, vol. 1, no. 1, pp. 15-25, 2005.

[95] D. E. Kelley, J. He, E. V. Menshikova, and V. B. Ritov, "Dysfunction of mitochondria in human skeletal muscle in type 2 diabetes," Diabetes, vol. 51, no. 10, pp. 2944-2950, 2002.

[96] M. E. Patti, A. J. Butte, S. Crunkhorn et al., "Coordinated reduction of genes of oxidative metabolism in humans with insulin resistance and diabetes: potential role of PGC1 and NRF1," Proceedings of the National Academy of Sciences of the United States of America, vol. 100, no. 14, pp. 8466-8471, 2003.

[97] K. Morino, K. F. Petersen, S. Dufour et al., "Reduced mitochondrial density and increased IRS-1 serine phosphorylation in muscle of insulin-resistant offspring of type 2 diabetic parents," Journal of Clinical Investigation, vol. 115, no. 12, pp. 3587-3593, 2005.

[98] K. F. Petersen, S. Dufour, D. Befroy, R. Garcia, and G. I. Shulman, "Impaired mitochondrial activity in the insulin-resistant offspring of patients with type 2 diabetes," The New England Journal of Medicine, vol. 350, no. 7, pp. 664-671, 2004.

[99] K. F. Petersen, D. Befroy, S. Dufour et al., "Mitochondrial dysfunction in the elderly: possible role in insulin resistance," Science, vol. 300, no. 5622, pp. 1140-1142, 2003.

[100] B. Andallu, B. Radhika, and V. Suryakantham, "Effect of aswagandha, ginger and mulberry on hyperglycemia and hyperlipidemia," Plant Foods for Human Nutrition, vol. 58, no. 3, pp. 1-7, 2003.

[101] S. Mahluji, V. E. Attari, M. Mobasseri, L. Payahoo, A. Ostadrahimi, and S. E. Golzari, "Effects of ginger (Zingiber officinale) on plasma glucose level, HbAlc and insulin sensitivity in type 2 diabetic patients," International Journal of Food Sciences and Nutrition, vol. 64, no. 6, pp. 682-686, 2013.

[102] T. Arablou, N. Aryaeian, M. Valizadeh, F. Sharifi, A. F. Hosseini, and M. Djalali, "The effect of ginger consumption on glycemic status, lipid profile and some inflammatory markers in patients with type 2 diabetes mellitus," International Journal of Food Sciences and Nutrition, vol. 65, no. 4, pp. 515-520, 2014.

[103] H. Mozaffari-Khosravi, B. Talaei, B.-A. Jalali, A. Najarzadeh, and M. R. Mozayan, "The effect of ginger powder supplementation on insulin resistance and glycemic indices in patients with type 2 diabetes: a randomized, double-blind, placebocontrolled trial," Complementary Therapies in Medicine, vol. 22, no. 1, pp. 9-16, 2014.

[104] A. Bordia, S. K. Verma, and K. C. Srivastava, "Effect of ginger (Zingiber officinale Rosc.) and fenugreek (Trigonella foenumgraecum L.) on blood lipids, blood sugar and platelet aggregation in patients with coronary artery disease," Prostaglandins Leukotrienes and Essential Fatty Acids, vol. 56, no. 5, pp. 379384, 1997.

[105] S. D. Jolad, R. C. Lantz, J. C. Guan, R. B. Bates, and B. N. Timmermann, "Commercially processed dry ginger (Zingiber officinale): composition and effects on LPS-stimulated PGE2 production," Phytochemistry, vol. 66, no. 13, pp. 1614-1635, 2005.

[106] S. D. Jolad, R. C. Lantz, A. M. Solyom, G. J. Chen, R. B. Bates, and B. N. Timmermann, "Fresh organically grown ginger (Zingiber officinale): composition and effects on LPS-induced
PGE2 production," Phytochemistry, vol. 65, no. 13, pp. 19371954, 2004

[107] S. M. Zick, Z. Djuric, M. T. Ruffin et al., "Pharmacokinetics of 6gingerol, 8-gingerol, 10-gingerol, and 6-shogaol and conjugate metabolites in healthyhuman subjects," Cancer Epidemiology Biomarkers and Prevention, vol. 17, no. 8, pp. 1930-1936, 2008.

[108] Y. Yu, S. Zick, X. Li, P. Zou, B. Wright, and D. Sun, "Examination of the pharmacokinetics of active ingredients of ginger in humans," AAPS Journal, vol. 13, no. 3, pp. 417-426, 2011.

[109] D. J. Newman and G. M. Cragg, "Natural products as sources of new drugs over the 30 years from 1981 to 2010," Journal of Natural Products, vol. 75, no. 3, pp. 311-335, 2012.

[110] B. D. Roufogalis, C. C. Duke, and V. H. Tran, "Preparation and pharmaceutical uses of phenylalkanols," PCT International Application 86, WO 9920589, 1999.

[111] B. D. Roufogalis, C. Duke, and V. Tran, "Medicinal uses of phenylalkanols and derivatives assigned to ZingoTX," Aust PN 758911; US PN 6518315; Canada PAN 2307028; Europe PN 1056700; NZ PAN 503976.

[112] N. Ede, B. Roufogalis, D. Owen, D. G. Bourke, H. Tran, and C. C. Duke, "Preparation of phenylalkanol derivatives as modulators of vanilloid receptor for treatment of pain PCT Int. Appl," WO 2006-AU710 20060526, Priority: AU 2005-902745, 20050527. CAN 146:7694 AN 2006:1252945, 2006.

[113] Y. Isa, Y. Miyakawa, M. Yanagisawa et al., "6-Shogaol and 6gingerol, the pungent of ginger, inhibit TNF- $\alpha$ mediated downregulation of adiponectin expression via different mechanisms in 3T3-L1 adipocytes," Biochemical and Biophysical Research Communications, vol. 373, no. 3, pp. 429-434, 2008.

[114] R. S. Ahmed and S. B. Sharma, "Biochemical studies on combined effects of garlic (Allium sativum Linn) and ginger (Zingiber officinale Rose) in albino rats," Indian Journal of Experimental Biology, vol. 35, no. 8, pp. 841-843, 1997.

[115] K. Srinivasan and K. Sambaiah, "The effect of spices on cholesterol 7 alpha-hydroxylase activity and on serum and hepatic cholesterol levels in the rat," International Journal for Vitamin and Nutrition Research, vol. 61, no. 4, pp. 364-369, 1991.

[116] L.-K. Han, X.-J. Gong, S. Kawano, M. Saito, Y. Kimura, and H. Okuda, "Antiobesity actions of Zingiber officinale Roscoe," Yakugaku Zasshi, vol. 125, no. 2, pp. 213-217, 2005.

[117] B. Fuhrman, M. Rosenblat, T. Hayek, R. Coleman, and M. Aviram, "Ginger extract consumption reduces plasma cholesterol, inhibits LDL oxidation and attenuates development of atherosclerosis in atherosclerotic, apolipoprotein E-deficient mice," Journal of Nutrition, vol. 130, no. 5, pp. 1124-1131, 2000. 

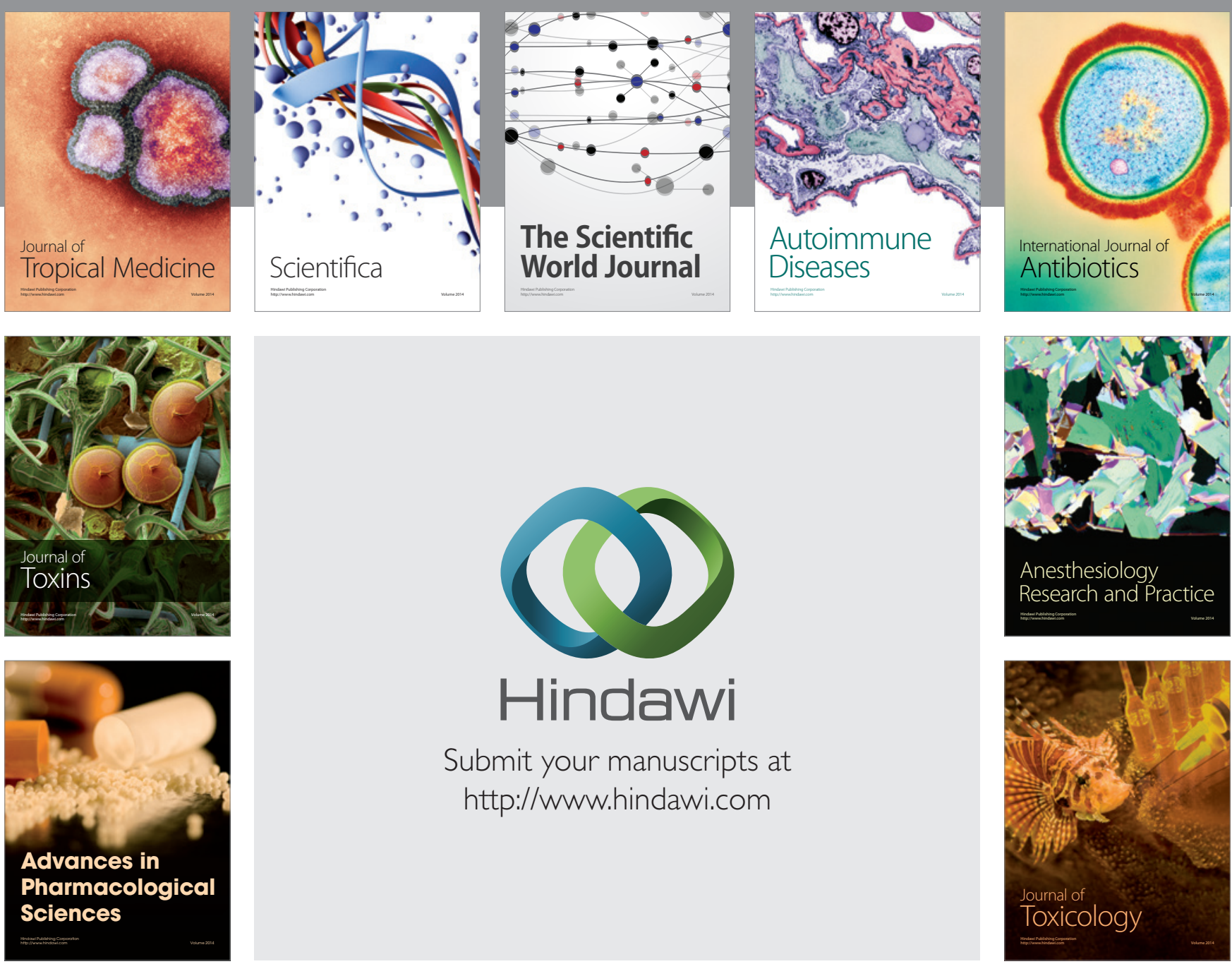

\section{Hindawi}

Submit your manuscripts at

http://www.hindawi.com
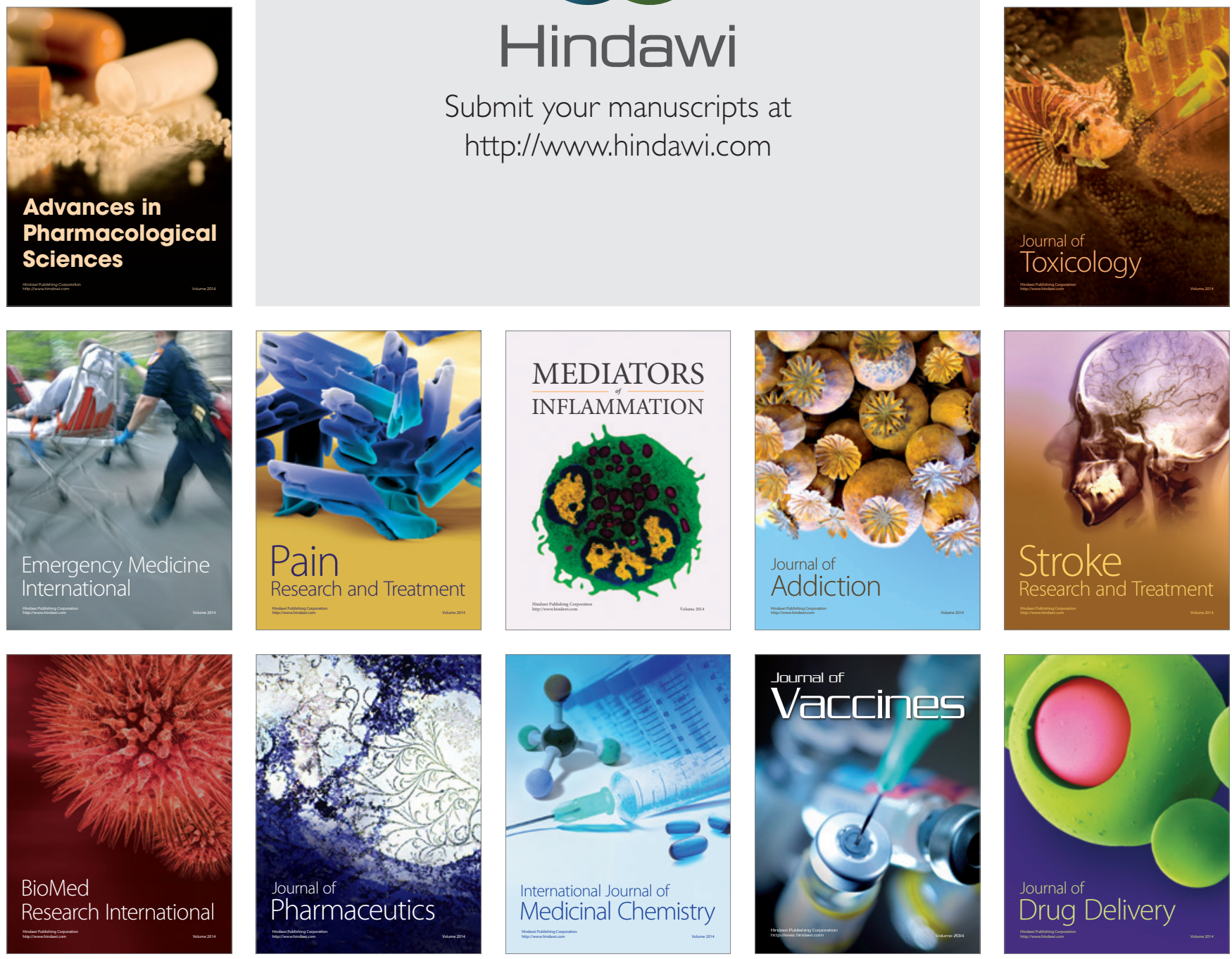